\title{
Hastanelerin Psikiyatri Hizmetlerinin Sunulduğu Birimlerde Görsel Sanatlar Eğitiminin Tamamlayıcı Tedavi Olarak Uygulanabilirliğine İlişkin Durumun İncelenmesi ${ }^{1}$
}

\author{
Zeynep GÖNÜLAY ÇALIMLI² ve Bülent SALDERAY3 \\ $\ddot{O} z$
}

Araştırmada, hastanelerin psikiyatri hizmetlerinin sunulduğu birimlerde görsel sanatlar eğitiminin tamamlayıc1 tedavi olarak uygulanabilirliğine ilişkin mevcut durumun ne olduğu sağlık çalışanlarının görüşlerine göre ele alınarak değerlendirilmiştir. Araştırmanın örneklemini ise; Ankara ilinde bulunan ruh sağlığı ve hastalıkları, çocuk ve ergen ruh sağlığı ve hastalıkları ve TRSM birimlerine sahip üç üniversite hastanesi ile Sağlık Bakanlı̆̆ına bağlı iki eğitim ve araştırma hastanesi içinde ilgili birimlerde çalışan sağlık personelleri oluşturmaktadır. Araştırmada, uzman görüşlerine dayalı olarak geliştirilen bir anket formu kullanılmış, verilerin analizi SPSS 22 paket programıyla yapılmış ve grafikler için excel programından faydalanılmıştır. Ankette yer alan açık uçlu sorulara verilen yanıtlar içerik analizi yöntemi ile derinlemesine incelenerek kategoriler oluşturulmuştur. Araştırmada; çalışmaya katılan sağlık personelinin görüşleri doğrultusunda görsel sanatlar yoluyla tedavi uygulamasının (a) psikiyatri birimlerinin \%49'unda yapıldığ1; (b) farklı meslek grupları tarafindan verildiği; ancak \%36 oranıyla sanat terapi uzmanı ve \%32 oranıyla uzmanlardan oluşan bir ekip tarafından verilmesini daha uygun gördükleri (c); kullanılan yöntem ve/veya tekniklere ilişkin \%73,23 oranla yanıt verilemediği ve/veya bilgi sahibi olmadıkları beyan edildiği; buna ek (d) "kil-seramik" çalışmalarını alanlarında en etkili uygulama olarak gördükleri (e) ve \%35,2 oranıyla "gerekli ve önemli bir yöntem olarak” görüldügü anlaşılmıştır.(f) Ayrıca çalışmaya katılan sağlık personelinin \%69 oranında görsel sanatların tedavi/terapi olarak kullanımına yönelik eğitim talep ettiği sonucuna ulaşılmıştır.

Anabtar Kelimeler: Görsel Sanatlar Eğitimi, Psikiyatri, Tamamlayıcı Tedavi, Sanat Terapi

Assessment and an Implementation Example of the Applicability of Visual Arts Education as a Complementary Treatment in the Hospital Units with Psychiatric Services

\begin{abstract}
The research evaluated the situation regarding the applicability of visual arts education as a complementary treatment in the units where the psychiatric services are provided in the hospitals was evaluated according to the opinions of the healthcare professionals. This group consisted of healthcare personnel working in related units within 3 University hospitals with mental health and diseases, children and adolescent mental health and diseases and CMHC units in Ankara and 2 training and research hospitals affiliated to the Ministry of Health. In this research, questionnaire form was used for the first part, data were analyzed with SPSS 22 package program and excel program was used for graphs. In this research; In line with the opinions of the healthcare personnel participating in the study, it was stated that (a) $49 \%$ of the psychiatric units performed the treatment through visual arts; (b) treatments were issued by different professional groups; however, they found it more appropriate to be given by a team of art therapists with a rate of $36 \%$ and a team of experts with a rate of $32 \%$ (c) $73.23 \%$ of the methods and/or techniques used were not answered and/or declared to be uninformed; (d) they consider "clay-ceramic" as the most effective application in their fields; (e) in that area $35.2 \%$ see the therapy "essential". Furthermore, it was found that (f) $69 \%$ of the health personnel participating in the study requested training for the use of visual arts as treatment/therapy.
\end{abstract}

Key Words: Visual Arts Education, Psychiatry, Complementary Therapy, Art Therapy

\section{Atıf İçin / Please Cite As:}

Gönülay Çalımlı, Z. ve Salderay, B. (2021). Hastanelerin psikiyatri hizmetlerinin sunulduğu birimlerde görsel sanatlar eğitiminin tamamlayıcı tedavi olarak uygulanabilirliğine ilişkin durumun incelenmesi. Manas Sosyal Arastirmalar Dergisi, 10(4), 2267-2288.

Geliş Tarihi / Received Date: 20.01.2021

Kabul Tarihi / Accepted Date: 26.06.2021

\footnotetext{
1 "Hastanelerin psikiyatri hizmetlerinin sunulduğu birimlerde görsel sanatlar eğitiminin tamamlayıcı tedavi olarak uygulanabilirliğine ilişkin durum tespiti ve bir uygulama örneği” isimli doktora tezinden üretilmiştir.

2 Dr. Öğr. Üyesi - Hatay Mustafa Kemal Üniversitesi Eğitim Fakültesi, zeynepgonulaycalimli@mku.edu.tr

ORCID: 0000-0002-7203-0546

${ }^{3}$ Prof. Dr. - Ankara Hacı Bayram Veli Üniversitesi Güzel Sanatlar Fakültesi, bsalderay@gmail.com

iD ORCID: 0000-0002-8133-6192.
} 


\section{Giriş}

Sanatın birçok tanımının olmasının yanında; sanatın disiplinler arası yapısından dolayı tek bir cümle ile tanımlanmasının zorluğu birçok araştırmacı tarafindan dile getirilmektedir. Bu doğrultuda; temel sanat kavramına dair yapılan tanımlamalar incelendiğinde, sanat kavrama farklı açılardan bakıldığı ve ele alınan yönü açısından sanatın değerlendirildiği anlaşılabilmektedir. Sanatın sanatsal üretim ile olan bağı, sanat tanımını farklı bir noktaya taşırken; eğitim, sağlık ... vb alanlar ile olan bağı ise onu tanımsal olarak daha farklı bir noktaya taşıyabilmektedir. Özellikle sanatın sağlık ile olan temel bağı onun sağlık alanındaki etken ve işlevsel olgusunu ortaya çıkarmaya yönelik yapılandığını gözler önüne serebilmektedir. Sanatın insan sağlığıyla olan ilişkisinden hareketle sanatın tanımı yapıldığında; bilincin yeniden düzenleyebileceği kazanımları sağlayarak yaratıcılık gücünü ortaya çıkaran, bu sayede insanın çevresiyle bir denge oluşturmasına yardım eden, konuşarak iletişime geçmenin yetersiz kaldığı alanlarda ifade özgürlüğü tanıyarak içe atılan duyguların sebep olduğu psikolojik baskı ve stresi azaltabilen ya da belli ölçüde telafi edebilen, içsel başarıyı sağlayabilen, yaşam kalitesini yükselten, sıkıntı ve gerginlikten kurtarılmaya yardımcı bir araç olarak tanımlanın doğru bir tanımlama şekli olduğu dile getirilebilir (Botton ve Armstrong, 2014, s. 5; Erinç, 2004, s. 12; Fischer, 1990; Mercin, 2011, s. 25; Özsoy, 2015, s. 32; Salderay, 2014a, s. 7; Yolcu, 2015, s. 45).

Belirtilenleri destekler nitelikte Salderay (2010); “geçmişten gelen bir bağın yansıması olarak görsel sanatlar, günümüz sağılk (tıp) alanında, tıbbi (medical) tedavinin yanında alternatif tedavi yöntemleri içerisinde; insanın sağlığa dayalı ihtiyaçlarını ve arzularını giderme noktasında kullanılmasıyla, rahatlatan ve güç veren bir aracı olarak görülmektedir” (s. 134-135) konuyu açıklamaktadır. Bu doğrultuda Botton ve Amstrong (2014) ise; görsel sanatlar, insanoğlunun doğuştan getirdiği bedensel zayıflıkların yanı sıra, daha çok zihinsel zayıflıkları yani psikolojik zaafları telafi eden bir araç olarak kullanıldığını vurgulamaktadır (s. 5). Bu bağlamda, görsel sanatların insan yaşamında iyi olma halini daha iyiye taşıyabileceğinden ve zor ya da sıkıntılı durumların atlatılmasında hastalık yaşayan bireye yardımcı konumda kullanılabileceğinden söz edilebilir.

Hastanın kendini sokabileceği tehlikeli ve yıkıcı yaklaşımlara bir seçenek olarak dikkatini başka yöne çeviren ve yeni bir uğraşma alanı veren sanat çabaları, sadece teşhiste yardımcı olabilecek bilgiler getirmesinin yanı sıra uğraştırma, iş ve meşguliyet yoluyla tedavi olarak iki farklı yönden de fayda sağlayabilir. Hastayı, içinde bulunduğu koşulları anlamada, yaşamış olduklarını değerlendirmede ve kendi bireysel ve toplumsal varlığına ilişkin farkındalık geliştirmede yönlendirici ve destekçi olabilmektedir. Uğraşı terapi olarak adlandırılan alan günlük yaşamdaki tüm aktivitelerin amaçlı bir şekilde terapist gözetiminde yapılması olarak tanımlanabilir (Büyükkınacı, 2010, s. 138). Demir (2017) göre ise; sanatsal etkinlikler, zaman öldürmek veya basit bir uğraşı olarak değil; ruhsal tedavinin bir parçası kabul edilebilir. Bireyin kendisini fiziksel, psikolojik ve ruhsal olarak ifade edebilecekleri farklı yollar bulmasını sağlar. Bu durum, ümitsizlik ve çare bulamadıkları durumlara yönelik öz denetimlerini geliştirerek mücadele becerilerini arttırır (s. 591). Bunun yanı sıra, sanatla uğraşmanın potansiyel bir birleştirici gücü vardır. $\mathrm{Bu}$ güçle bireyin hem duygusal hem de bilişsel süreçleri desteklenir, bu sayede bireyin kendi iç ve dış parçalarını onarmasında yardımcı olur. Belirtilenlere ek olarak psikolojik rahatsızlık yaşayan hastaların yapmış oldukları resimler ya da diğer sanat çalışmaları, hastalıklarının tanılanmasında mevcut özelliklerin belirlenmesinde veya hastanın çevreyle olan bağlantı kurabilme yetenekliliğini açığa vurmada da katk1 sağladığ1 düşünülebilmektedir (Botton ve Armstrong, 2016, s. 12; Salderay, 2013, s. 200; Utaş Akhan, 2012, s. 133).

Alternatif tedavi yöntemleri içerisinde yer alan görsel sanatlar yoluyla tedavi; anksiyete (kaygi) ve depresyon hastalarında, şizofreni hastalarında, travma sonrası stres bozukluğunda, bağımlılıkta, aile ve ilişki sorunlarında, ergenlik ve hastalıkla ilgili sosyal ve duygusal zorluklarda, travma-kayıp ve yas durumlarında, bilişsel, fiziksel ve nörolojik sorunlarda tıbbi hastalıklarla ile ilgili psiko-sosyal zorluklarda, stresle başa çıkmada ya da kişisel gelişim talep edilen durumlarda uygulanabilmektedir (Salderay, 2014, s. 8). Belirtilenler doğrultusunda; ruhsal bozukluklar yaşayan hastalarla alternatif ve tamamlayıcı tedavi yöntemi olarak kabul edilen görsel sanatlar yoluyla tedavi uygulamalarının, hastalar üzerinde olumlu etkiler bırakabileceği ve hastalıklarından kaynaklı sıkıntılı durumları aşmada rol oynayabileceği dile getirilebilir.

Sağlık Bakanlığı tarafindan hazırlanan “Türkiye'de Ruhsal Bozuklukların Yaygınlığı ve Hastalık Yükü” raporuna göre; ulusal düzeyde hastalık yükü nedenlerinin temel hastalık gruplarına göre dağılımı yapıldığında, kardiyovasküler (kalp ve kan damarı hastalıklarının genel adı) hastalıklarından sonra \%19 ile ikinci sırada psikiyatrik hastalık grubunun yer aldığı görülmektedir. Çalsşmayı yürüten araştırmacılar, 
Türkiye'de hem kentsel hem de kırsal alanda ruhsal bozuklukların önemli hastalı yükü oluşturduğu yorumunu getirmektedirler (Sağlık Bakanlığı, 2011 s. 5-6). Bunun yanı sıra kanser ve benzer ciddi rahatsızlıklar getirdiği cerrahi müdahaleler ve günlük yaşantının yerine getirilmesini zorlaştıran durumlar ya da geleceğe karșı umutsuzluk gibi düșünceler; duygusal, bilișsel ve fiziksel alanda dağılma, korku, kayg1, çaresizlik gibi duyguları oluşturur. Bu durum depresyon ve benzeri psikolojik sıkıntılara da yol açabilir (Gönülay Çalımlı, 2014, s. 16).

Ruhsal bozuklukların tedavisinde sıklıkla kullanılan yöntemlerden biri de psikoterapidir. Psikoterapi, bir tedavi ediciyle (danışman, terapist vs.) bir ya da bir grup hasta (danışan) arasında gerçekleşen, tanı koydurucu ve tedavi edici niteliği olduğu varsayllan ilişkidir (Oğuz, 2001, s. 37). Bütün psikoterapi türlerinin öğrenme faaliyeti sağlayan yeni bilgi veya yeni duygusal değişikliklerin hastaya yarar sağladığ1 bilinmektedir. Deneyimsel öğrenmelerde ise hastanın tutum ve davranışlarından takip edilebilirliği, bilişsel öğrenmelere göre çok daha fazla olduğu gözlemlenmektedir. Bu durum duygusal uyarılma durumunu da beraberinde getirmektedir. Duygular, kişinin kendisini değiştirmesi için itici güç kaynağıdır ve kişinin kendisini değiştirmesine katkı sağlar. Duygular, tutum değişikliğini kolaylaştırır ve çevresel etkilere daha duyarlı hale getirir (Frank, 1985, s. 3). Bu duyarllıktan hareketle "terapötik ortam" ya da "tedavi edici ortam" kavramlarının ortaya çıktığından bahsedile bilinir. Tedavi edici ortam gerek dünyada gerekse Türkiye'de çağdaş psikiyatri anlayışının temelini oluşturmaktadır. Türkiye'de uygun psikiyatri ünitelerinin oluşması için değişik çalışmalar yapılmaktadır. Bunlar: ünitelerin fiziksel şartlarının iyileştirilmesi, yatak kapasitelerinin arttırılması, tedavi alan bireylere uğraşı etkinliklerini gerçekleştirebilecekler alanların oluşturulması vb. şeklindedir (Ergün, Işık ve Dikeç, 2015, s. 3). Bu noktada, görsel sanatların hem deneyimsel öğrenme faaliyetleri içererek psikoterapiye yardımcı olabileceği gibi hem de yapılandırılmış görsel sanatlar atölyeleri ile de terapötik ortamın hastalar üzerinde olumlu etki sağlayabileceği dile getirilebilir. Gelişmiş birçok ülkede hastane bünyeleri içerisinde hastaların ihtiyaçları düşünülerek tasarlanan görsel sanatlar atölyelerinin, ilgili bakanlıklar ve kurumlar tarafından yapılandırıldı̆̆1 görülmektedir. Ancak; Türkiye'de Sağlık Bakanlığına bağlı hastanelerde, hastalar için oluşturulmuş görsel sanatlar atölyelerinin mevcut olmadığ dile getirilebilir. Görsel sanatlar atölyeleri psikiyatrik hastalar veya steril (arındırlmış) ortama ihtiyaç duyan hastalar gibi özel durumlara yönelik tasarlanabilen yani yapılandırılan atölyeler olmakla birlikte bu atölyelerin sağlık kurumlanında yer almasının gerekliliğinden bahsedilebilmektedir (Salderay, 2013, s. 203).

Türkiye'de bazı hastanelerde bazı hasta gruplarına kısa dönemli görsel sanatlar çalışmalarının uygulandığı bilinmektedir. Ancak Salderay'a göre (2013) bu uygulamalar hastanın tedavi süreci içerisinde ele alınan, tıbbı anlamda desteklenen, sistematik ve bilimsel bir programa bağlı ve uzman kişiler tarafindan yapilan uygulamalar değildir (Salderay, 2013, s. 203).

Görsel sanatlar yoluyla tedavi, kişinin birebir sağlığını ilgilendiren hususlar olduğu için konu disiplinler arası bir yaklaşımla "uzmanlar" tarafından (psikiyatrist, psikolog gerek teoride gerekse uygulamada konuya hakim görsel sanatlar eğitimcisi ve diğer yardımcı sağlık personeli) ele alınmalı, değerlendirilmeli ve uygulanmalıdır. "Aksi bir yaklaşım doğrudan kişinin sağlığını etkileyebilecektir" (Salderay, 2014a, s. 8). Bu doğrultuda; alanda çalışan sağlık çalışanlarının görsel sanatlar uygulamaları konusundaki temel bilgi ve beceri dayalı yeterlilikleri ile görsel sanat eğitimcilerinin hasta psikopatolojisi ve tanılamalar ile ilgili yeterliliklerinin kısıtlllığı alanda temel problemlerin oluşmasına zemin oluşturduğu dile getirilebilir.

$\mathrm{Bu}$ konuyla ilgili yapılan araştırmaların da bu görüşü destekler nitelikte olduğu söylenebilir. Bu doğrultuda, Kinney ve Rentz (2005), yapılan çalışmada program dahilindeki uzmanlar tarafindan yaratıcillğın artmasını sağlayan görsel sanatlar yoluyla terapinin uygulamalı basit el işi aktivitelerine oranla hastalara (yararlanıcılara) daha fazla ilgi, heves ve benlik saygisı duygularının oluşturduğunu bulgulamışlardır (Kinney ve Rentz, 2005, s. 221; Malchiodi, 2005, s. 132; Salderay, 2014a, s. 7). Diğer bir araştırmada Pénzes, Van Hooren, Dokter, Smeijsters ve Hutschemaekers (2014) belirli özelliklere sahip sanat malzemeleriyle etkileşimin, hastaların ruh sağlığıyla ilgili özelliklerini yansıttığını gösterdiğinden bahsetmektedirler. Bu doğrultuda seçilen sanat malzemeleri, özeliklerine uygun bir metotla uygulandığ1 zaman hastanın malzemeyle etkileşimi gözlenerek hastanın ruh sağlı̆ı hakkında bilgi edinilmesinin sağladığının da bulunduğu ifade edilmektedir (Pénzes vd., 2014, s. 484). Dolayısı ile kendini ifade etmekte zorlanan hastalar için sanatsal malzeme tabanlı etkileşimin alanda yetkin uzmanlar tarafindan doğru ve profesyonel bir yaklaşımla uygulandığında değerli bir yaklaşım ola bileceği dile getirilebilir.

Türkiye'de görsel sanatlar yoluyla tedavinin, psikiyatri hizmeti veren sağlık kurumlannda uygulanma durumuna ilişkin güncel durumun nasıl olduğu bilinmemektedir. Ayrıca; hastanelerin psikiyatri 
hizmetlerinin sunulduğu birimlerinde görsel sanatlar yoluyla tedavi uygulamalarının yapılıp yapılmadığı da bilinmemektedir. Bunun yanı sıra; eğer yapılıyorsa yapılan görsel sanatlar yoluyla tedavi uygulamalarının hangi koşullarda ve ortamlarda kimler tarafindan, nasıl uygulandığının bir durum tespitiyle ortaya çıkarılmasına ihtiyaç duyulmaktadır. Bu ihtiyaç ve gereksinimden hareketle; "hastanelerin psikiyatri hizmetleri sunan birimlerinde görsel sanatlar eğitiminin tamamlayıc1 tedavi olarak uygulanabilirliğine ilişkin durum tespiti" problem olarak belirlenmiş ve araştırma bu çerçevede ele alınarak irdelenmiştir.

\section{Yöntem}

$\mathrm{Bu}$ araştırma, nicel tarama modeline bağlı betimsel bir çalışmadır. Bu doğrultuda; verilere ulaşabilmek için uzman görüşleriyle oluşturulan anket formu kullanılmıstır. Daha açık bir ifade ile; örneklem olarak belirlenen hastanelerin ve bölümlerin psikiyatri hizmetlerinin sunulduğu birimlerinde, görsel sanatlar yoluyla tedavi (terapi) ile ilgili olan betimsel tarama modeli kullanılmıştır. Bu model güncel durumu betimlemeye yönelik kullanılmıştır. Betimsel araştırma; zaman zaman mevcut durumla, olayı etkileyen veya etkilemeyen önceki bazı olaylarla ve ne veya neyin var olduğuyla ilişkilidir. Diğer bir ifadeyle betimsel araştırma; mevcut şartlar veya ilişkilerin, güncel uygulamaların, devam eden süreçlerin, inançların, tutumlar ve/veya bakış açıları gibi etkileri hissedilen durumların veya gelişmekte olan trendlerin yapısını tanımlamak için etkileri hissedilen durumların veya gelişmekte olan trendlerin yapısını tanımlamak için kullanılan araştırma yöntemidir (Cohen, Manion ve Morrison, 2007, s. 205). Sönmez ve Alacapınar (2014)'a göre ise, betimsel araştırma; yaşayanların, hali hazırda var olanların, yaşananların ne olduğunun betimlenip açıklanarak ortaya konulması olarak ele alınabilir (s. 47).

"Hastanelerin psikiyatri hizmetlerinin sunulduğu birimlerinde görsel sanatlarla yapılan çalışmaların, tamamlayıc1 tedavi olarak uygulanmasinda mevcut durum nedir?" sorusuna yanit bulmak amaciyla ise nicel araştırmalarda veri toplama araçlarından biri olan anket kullanmıştır. Araştırmanın bu kısmında bağımsız değişken, araştırmacı tarafından oluşturulan ankettir. Bağımlı değişken, örneklemde belirlenen hastane ve bölümlerde çalışan sağlık personelinin vermiş olduğu yanıtlardır.

\section{Evren - Örneklem}

Araştırma için seçilen evren Ankara ilidir. Araştırma kapsamında karşılaşılan sınırllıklar çerçevesinde araştırmanın örneklemini ise Ankara Hacettepe Üniversitesi Tip Fakültesi Hastanesi Ruh Sağlı̆ı ve Hastalıkları Bölümü, Ankara Üniversitesi Tip Fakültesi Cebeci Araştırma ve Uygulama Hastanesi Çocuk Ergen Ruh Sağlığ1 ve Hastalığ1 Bölümü, Ankara Üniversitesi Tip Fakültesi Cebeci Araştırma ve Uygulama Hastanesi Ruh Sağllğı ve Hastalıkları Bölümü, Ankara Gazi Üniversitesi Sağlık Araştırma ve Uygulama Merkezi Çocuk Ergen Ruh Sağlığ1 ve Hastalı̆̆1 Bölümü, Ankara Gazi Üniversitesi Sağlık Araştırma ve Uygulama Merkezi Ruh Sağlığı ve Hastalıkları Bölümü, Dış Kap1 Eğitim ve Araştırma Hastanesi Toplum Ruh Sağlı̆̆1 Merkezi ve Dr. Abdurahman Yurtaslan Ankara Onkoloji Eğitim ve Araştırma Hastanesi Andiçen Toplum Ruh Sağlı̆̆ Merkezi'nde çalışan sağlık personelleri oluşturmuştur. Araştırmanın örneklemine ilişkin bilgiler tablo 1 ve 2 de detaylı olarak belirtilmiştir.

Tablo 1. Katıllmonclarm Callstğğ Kurumlar

\begin{tabular}{lll}
\hline \multicolumn{1}{c}{ Kurumlar } & $\mathbf{f}$ & $\mathbf{\%}$ \\
\hline Ankara Hacettepe Üniversitesi Tip Fakültesi Hastanesi & 15 & 21,1 \\
Ankara Üniversitesi Tip Fakültesi Cebeci Araştırma ve Uygulama Hastanesi & 19 & 26,8 \\
Ankara Gazi Üniversitesi Sağlık Araştırma ve Uygulama Merkezi & 20 & 28,2 \\
Dışkapı Ë̆itim ve Araştırma Hastanesi Toplum Ruh Sağlı̆̆ı Merkezi & 8 & 11,3 \\
Dr. Abdurrahman Yurtaslan Ankara Onkoloji Ĕ̆itim ve Araştırma Hastanesi & 9 & 12,7 \\
\hline Toplam & 71 & 100 \\
\hline
\end{tabular}

Tablo 1 incelendiğinde, katılımcıların 20'si (\%28,2) Ankara Gazi Üniversitesi Sağlık Araştırma ve Uygulama Merkezin'den; 19’u $(\% 26,8)$ Ankara Üniversitesi Tip Fakültesi Cebeci Araştırma ve Uygulama Hastanesi'nden; 15’i (\%21,1) Ankara Hacettepe Üniversitesi Tip Fakültesi Hastanesi'nden; 8’i $(\% 11,3)$ Dışkapı Eğitim ve Araştırma Hastanesi'nden ve 9'u (\%12,7) Dr. Abdurrahman Yurtaslan Ankara Onkoloji Eğitim ve Araştırma Hastanesi'nden araştırmaya katıldığı görülmektedir. Bu araştırmaya toplam 71 sağlık personeli katılmıstır. 
Tablo 2. Katılımcılarn Hastanede Calıștı̆̆ Birimler

\begin{tabular}{lllll}
\hline & \multicolumn{2}{c}{ Çalışıor } & \multicolumn{3}{c}{ Çalışmıyor } \\
& $\mathrm{f}$ & $\%$ & $\mathrm{f}$ & $\%$ \\
\hline Çocuk ve Ergen Ruh Sağlığı ve Hastalıkları Poliklinik & 16 & 22,5 & 55 & 77,5 \\
Erişkin Ruh Sağlığı ve Hastalıkları Poliklinik & 38 & 53,5 & 33 & 46,5 \\
Erişkin Ruh Sağlı̆̆ı ve Hastalıkları Yataklı Servis & 19 & 26,8 & 52 & 73,2 \\
Toplum ve Ruh Sağlığı Merkezi (TRSM) & 17 & 23,9 & 54 & 76,1 \\
\hline
\end{tabular}

Tablo 2 incelendiğinde, katılımcıların 37’si, (\%52,1) büyük bir çoğunluğu Erişkin Ruh Sağlı̆̆1 ve Hastalıkları Polikliniği’nde çalışmaktadır. Katılımcıların 26's1 (\%36,6) Erișkin Ruh Sağlığı ve Hastalıkları Yataklı Servisi'nde; 17'si (\%23,9) Toplum ve Ruh Sağllğı Merkezi'nde ve 17'si (\%23,9) Çocuk ve Ergen Ruh Sağlığı ve Hastalıkları Polikliniği’nde çalışmaktadır. Erişkin Ruh Sağlığı ve Hastalıkları Poliklinik ile Yataklı Servisi'nde çalışan 8 kişi; Çocuk ve Ergen Ruh Sağlığı ve Hastalıkları Poliklinik Ek Erişkin Ruh Sağlığ1 ve Hastalıkları Poliklinik ile Yataklı Servisi'nde çalışan 3 kişi; Erişkin Ruh Sağlığ1 ve Hastalıkları Poliklinik ile TRSM'de çalışan 5 kişi ve Erişkin Ruh Sağlığı ve Hastalıkları Poliklinik ile Yataklı Servis ve TRSM'de çalışan 1 kişi bulunmaktadır.

Araştırma kapsamında incelenen kurumlarda Erişkin Ruh Sağlı̆̆ı ve Hastalıkları Yataklı Servis/Polikliniği, Çocuk ve Ergen Ruh Sağlığı ve Hastalıkları Polikliniği ve Toplum Ruh Sağlığı Merkezi (TRSM) bulunmakla birlikte AMATEM (1), Bağımlık birimi (1), Geriatrik Polikliniği (1), Ergen Ruh Sağllğı Birimi (1) gibi birimlerin de bulunduğu belirlenmiştir. AMATEM ve Geriatrik Polikliniği erişkin ruh sağlığ1 kategorisinde; ergen ruh sağlı̆̆ birimi ise çocuk ve ergen ruh sağlığı ile değerlendirilmiştir.

\section{Veri Toplama Aracı}

Araştırmanın verilerinin toplanması için literatür ışı̆̆ında araştırmacı tarafindan anket formu oluşturulmuştur. Oluşturulan anket formu; 1 sanat eğitimcisi, 1 özel görsel sanatlar uzmanı, 1 psikolog, 1 çocuk psikiyatristi ve 1 özel eğitimciye gösterilerek uzman görüşleri alınmıştır. Uzman görüşleri doğrultusunda oluşan anket formunun pilot uygulaması Ankara Gazi Üniversitesi Sağlık Araştırma ve Uygulama Merkezi Çocuk ve Ergen Psikiyatri Bölümü'nde çalışan seçilmiş altı sağlık personeliyle yapılmıştır. Pilot uygulamaya katılan sağılk personeli, gerçek uygulamada kapsam dışında bırakılmıştır. Araştırmacının kişisel bağlantıları sayesinde bu birimde, pilot uygulamanın yapilması, daha sağlıklı sonuçların alınabilmesine imkan sağlamıştır. Pilot uygulama sonrasında, uzman görüşleriyle birlikte anket formu üzerinde gerekli düzenlemeler yapılmışır. Oluşan yeni anket formu, örneklem olarak tespit edilen hastanelere araştırmacı tarafından bizzat ulaştırlmıştır. Anket formlarındaki soruların, psikiyatri kliniklerindeki yetkili sağlık personeli (klinik doktoru, asistanı, psikolog, hemşire ve/veya sosyal hizmet uzmanı) tarafından doldurulması istenmiştir. Uzman görüşleri doğrultusunda son hali oluşturulan ölçeğin giriş kısmında, sağlıklı sonuçlar elde edebilmek için anket içerisinde geçen terimlerin açıklamaları yer almıştır; bu açıklamaların da anket doldurulmadan önce okunması talep edilmiştir. Bu araştırmada, verilerin toplamasındaki araç olan anket formunun alan kapsam geçerlikleri uzman görüşüne dayalı olarak incelenmiştir.

\section{Verilerin Analizi}

Ankara ilindeki hastanelerde görsel sanatlar yoluyla tedavinin kullanılma durumunu ortaya koymak amacıyla yapılan bu çalışmada araştırmacı tarafindan geliştirilen anket kullanılmıştır. Toplanan veriler bilgisayar ortamına aktarılıp ankette yer alan maddeler frekans ve yüzde istatistikleri kullanılarak yorumlanmışır. Analizler SPSS 22 paket programı ile yapılmıştır. Grafiklerin çiziminde Excel programından faydalanılmıştır. Ayrıca ankette yer alan açık uçlu sorulara verilen yanıtlar içerik analizi yöntemi ile derinlemesine incelenerek kategoriler oluşturulmuştur.

\section{Bulgular}

Ankara ili içerisinde yer alan hastanelerin psikiyatri birimlerinde görsel sanatlar yoluyla tedavi ile ilgili bu birimlerde çalışmaya katılan sağlık personelin (klinik doktoru ve asistanı, psikolog, hemşire ve/veya sosyal hizmet uzmanı) görüşlerine ait bulgular aşağıda sunulmuştur. 


\section{Alt Amaçlarla İlgili Bulgular}

(a) Psikiyatri Birimlerinde Görsel Sanatlar Yoluyla Tedavi (Terapi) Uygulamasının Varlı̆ı̆na

İlişkin Bulgular: Görsel sanatlar yoluyla tedavi uygulamasının var olma durumu sorgulanmıştır. Görüşler doğrultusunda ortaya çıkan bulgular Şekil 1'de sunulmuştur.

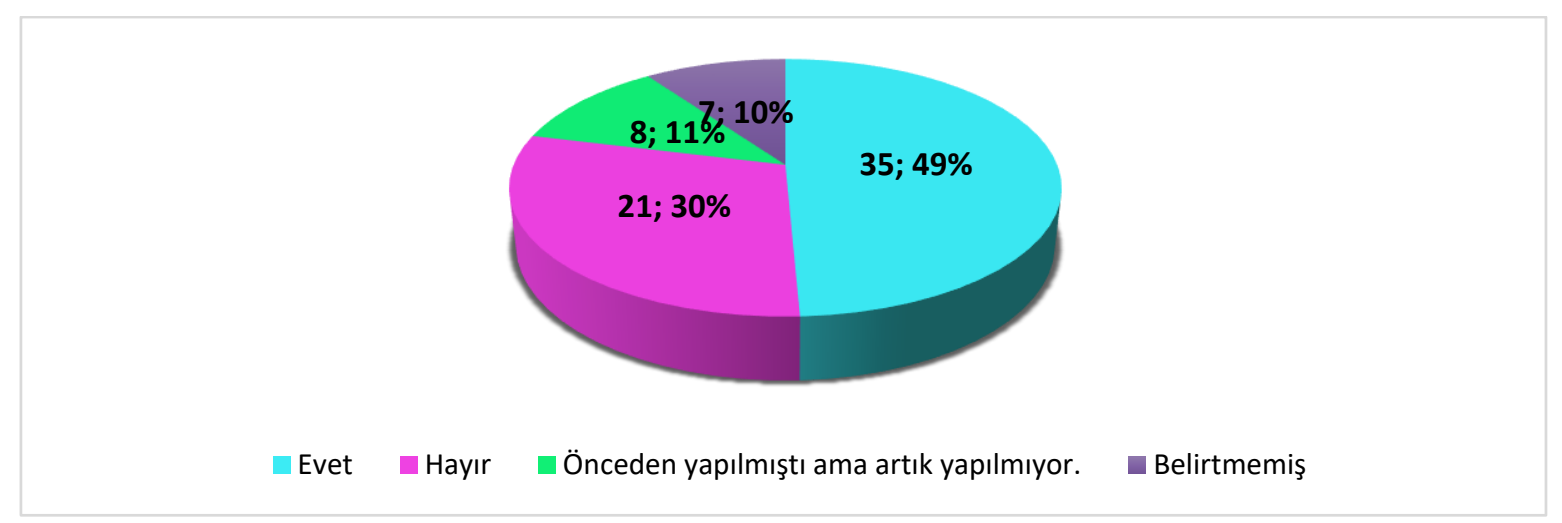

Şekil 1. Görsel Sanatlar Yoluyla Tedavi Uygulamasmmn Var Olma Durumunun İncelenmesi

Şekil 1 incelendiğinde katılımcıların \%49’u ( $f=35$ ) çalıştıkları birimlerde görsel sanatlar yoluyla tedavi uygulaması yapıldığını belirttikleri görülmüştür. Katılımcıların \%30’u ( $\mathrm{f}=21)$ çalıştıkları birimde görsel sanatlar yoluyla tedavi uygulamasının yapılmadığını; \%11’i $(\mathrm{f}=8)$ ise önceden görsel sanatlar yoluyla tedavi uygulamasının yapıldığını ancak araştırmanın gerçekleştirildiği zaman aralığında yapılmadığını belirtmiştir. Katılımcıların arasından 7 kişi bu soruya yanıt vermemiştir. Bu araştırmanın verilerinden hareketle katılımcıların \%49 ( $\mathrm{f}=35)$ oranındaki büyük çoğunluğunun görsel sanatlar yoluyla tedavi uygulamasını birimlerindeki hastalara sundukları görülmektedir.

b) Görsel Sanatlar Yoluyla Tedavinin Uzmanlık Alanına Yönelik Bulgular: Görsel sanatlar yoluyla (tedavi) uygulamasını; "hali hazırda" veren kişilerin uzmanlık alanları, sağlık personelinin görüşleri doğrultusunda belirlenmiştir. Sonuçlar Tablo 3'de sunulmuştur. Buna ek olarak, araştırmaya katılan sağlık personelinin görsel sanatlar yoluyla tedavi (terapi) rehabilitasyonu ve/veya eğitimi veren kişilerin uzmanllk alanlarının "ne olması gerektiği”" konusundaki görüşleri incelenmiştir. Sonuçlar Tablo 4'de sunulmuştur.

Tablo 3. Görsel Sanatlar Yoluyla Tedavi (Terapi) Uygulamasmı Veren Personelin Uzmanlle. Alanlar (Mevcut Durum)

\begin{tabular}{lcccc}
\hline \multicolumn{1}{c}{ Görsel Sanatlar Yoluyla Tedavi } & \multicolumn{2}{c}{ Veriyor } & \multicolumn{2}{c}{ Vermiyor } \\
\hline Doktor & $\mathrm{f}$ & $\%$ & $\mathrm{f}$ & $\%$ \\
Hemşire & 17 & 23,9 & 54 & 76,1 \\
Hasta Bakıc1 & 11 & 15,5 & 60 & 84,5 \\
Sanat Terapi Uzmanı & 2 & 2,8 & 69 & 97,2 \\
Görsel Sanatlar Öğretmeni & 6 & 8,4 & 65 & 91,6 \\
Sosyal Hizmetler Uzmanı & 18 & 25,4 & 53 & 74,6 \\
Diğer & 4 & 5,6 & 67 & 94,4 \\
\hline
\end{tabular}

Tablo 3 incelendiğinde çalşmaya katılan sağlık personelinin görüşleri doğrultusunda görsel sanatlar yoluyla (tedavi) uygulamasını sunan kişilerin uzmanlı alanlarının; \%25,4'ü ( $\mathrm{f}=18$ ) görsel sanatlar öğretmeni, \%23,9'unun ( $f=17$ ) doktor, $\% 15,5$ 'inin ( $f=11$ ) hemşire, $\% 8,4$ '̈̈nün ( $f=6)$, sanat terapi uzmanı, $\% 5,6$ 'sının ( $f=4$ ) sosyal terapi uzmanı ve $\% 2$, 8'inin $(f=2)$ hasta bakıcı olduğu bulgulanmıştır. Diğer seçeneğinde yanıt belirten katılımcılardan \%15,5’inin ( $f=11)$ yoğunluklu olarak; el sanatları öğretmeni, ergoterapist, psikolog ve uğraşı öğretmeni yanıtlarını verdikleri görülmektedir. Bu soruya verilen cevaplar çoklu yanıt olduğundan toplamları \%100'ü geçer; diğer bir değişle " $n$ " sayısı (katılımc1 sayısı), örneklem hacmini geçmektedir. Bu soru kapsamında beş seçenek işaretleyen katıllımcı, sırasıyla: "doktor, hemşire, hasta bakıcı, görsel sanatlar öğretmeni ve sosyal hizmet uzmanı" seçimlerini yapmıştır. Üç seçenek işaretleyen katılımcılar ise bir kişi "doktor, hemşire, hasta bakıcı"; bir kişi "doktor, hemşire, sanat terapi uzmanı"; diğer bir kişi ise "doktor, sanat terapi uzmanı, görsel sanatlar öğretmeni” cevaplarını verirken iki seçenek işaretleyen katıllımcıların sırayla üçü "doktor ve hemşire"; ikisi "doktor ve sanat terapi uzmanı"; üçü "doktor ve görsel sanatlar öğretmeni”; ikisi "doktor ve sosyal hizmet uzmanı”; ikisi “ 
hemşire ve görsel sanatlar öğretmeni”; bir kişi "hemşire, diğer"; bir kişi "sanat terapi uzmanı ve görsel sanatlar öğretmeni”" seçeneklerini birlikte seçmiştir.

Tablo 4. Görsel Sanatlar Yoluyla Tedavi (Terapi) Rebabilitasyonu ve/veya Eğitimi Veren Kişilerin Užmanlı Alanlarmm Ne Olması Gerektiğine Yönelik Görüsleri

\begin{tabular}{lcccc}
\hline \multicolumn{1}{c}{ Görsel Sanatlar Yoluyla Tedavi } & \multicolumn{2}{c}{ Vermeli } & \multicolumn{2}{c}{ Vermemeli } \\
\hline Doktor & $\mathrm{f}$ & $\%$ & $\mathrm{f}$ & $\%$ \\
Hemşire & 14 & 19,7 & 57 & 80,3 \\
Hasta Bakıc1 & 14 & 19,7 & 57 & 80,3 \\
Sanat Terapi Uzmanı & 4 & 5,6 & 67 & 94,4 \\
Görsel Sanatlar Ögretmeni & 36 & 50,7 & 35 & 49,3 \\
Sosyal Hizmetler Uzmanı & 26 & 36,6 & 45 & 63,4 \\
Ekip (farklı alanlardan uzmanlarla birlikte yapılmalı) & 11 & 15,5 & 60 & 84,5 \\
Diğer & 32 & 45,0 & 39 & 55,0 \\
\hline
\end{tabular}

Tablo 4 incelendiğinde katılımcıların çoğunluğunun -\%50,7’sinin ( $\mathrm{f}=36$ )- görsel sanatlar yoluyla tedavi (terapi) rehabilitasyonu ve/veya eğitimi veren kişilerin, alanının sanat terapi uzmanı olması gerektiğini düşündükleri görülmektedir. Katılımcıların ikincil çoğunlukla -\%45’inin (f=32)- uzlaştıkları yanıt, farklı alanlardan uzmanlar ile oluşturulmuş bir ekip tarafindan görsel sanatlar yoluyla tedavi (terapi) rehabilitasyonu ve/veya eğitimi verilmesi gerektiğini belirtirken; üçüncül çoğunlukla \%36,6'sının (f=26) görsel sanatlar öğretmenlerinin görsel sanatlar yoluyla tedavi (terapi) rehabilitasyonu ve/veya eğitimi vermesi gerektiğini düşündükleri anlaşılmaktadır. Bir diğer çoğunluk \%19,7 ( $\mathrm{f}=14)$ doktor ve $\% 19,7$ ( $\mathrm{f}=14)$ hemşire cevapları altında \%39,4 $(\mathrm{f}=28)$ oranında görüşlerin toplandığı görülmektedir. Daha sonra sırasıla, \%15,5 (f=11) sosyal hizmetler uzmanı, \%5,6 ( $\mathrm{f}=4$ ) hasta bakıcı ve \%4,2 (f=3) diğer seçenekleri düşündükleri görülmektedir. Bu soruya katıllımciların 26's1 cevap vermemiştir. Bu soruya verilen cevaplar çoklu yanıt olduğundan toplamları \%100'ü geçer diğer bir deyişle "n" sayısı (katılımcı sayısı), örneklem hacmini geçmektedir. Bu soru kapsamında yedi seçenek işaretleyen üç katıllımcı, sırasıyla: "doktor, hemşire, hasta bakıcı, sanat terapi uzmanı, görsel sanatlar öğretmeni, sosyal hizmet uzmanı ve ekip" seçimlerini yapmıştır. Altı seçenek işaretleyen dört katılımcı, sırasıyla: "doktor, hemşire, sanat terapi uzmanı, görsel sanatlar öğretmeni, sosyal hizmet uzmanı ve ekip" seçerken; beş seçenek işaretleyen iki katıllımc1 "doktor, hemşire, sanat terapi uzmanı, görsel sanatlar öğretmeni ve sosyal hizmet uzmanı" cevaplarını vermişlerdir. Üç seçenekte yoğunlaşan on bir katılımcının beşi "sanat terapi uzmanı, görsel sanatlar öğretmeni ve ekip"; ikisi "hemşire, sanat terapi uzmanı ve görsel sanatlar öğretmeni"; biri "doktor, hemşire, ve sanat terapi uzmanı"; biri "hasta bakıcı, sanat terapi uzmanı ve ekip"; biri "sanat terapi uzmanı, görsel sanatlar öğretmeni ve diğer"; diğer biri ise, " sosyal hizmet uzmanı, ekip ve diğer" seçenekleriyle görüş bildirmişlerdir. İki seçenek seçen on iki katılımcının beşi "sanat terapi uzmanı ve görsel sanatlar ögretmeni”"; üçü "sanat terapi uzmanı ve ekip"; biri "doktor ve hemşire"; biri "hemşire ve sanat terapi uzmanı"; biri "görsel sanatlar öğretmeni ve ekip" ve diğer biri ise "ekip ve diğer" olarak görüşlerini bildirmiştir.

c) Görsel Sanatlar Yoluyla Tedavi Uygulamasında Kullanılan Yöntem ve/veya Tekniklere Iliş̧kin Bulgular: Görsel sanatlar yoluyla (tedavi) uygulamasında kullanılan teknikler, sağlık personelinin görüşleri doğrultusunda belirlenmiştir. Katılımcıların sonuçları Tablo 5’te sunulmuştur.

Tablo 5. Görsel Sanatlar Yoluyla Tedavide Kullamlan Yöntem ve/ veya Teknikler

\begin{tabular}{|c|c|c|}
\hline Kategoriler & f & $\%$ \\
\hline Yanitsiz & 36 & 50,70 \\
\hline Birimlerinde bu tedavi yöntemi kullanılmıyor ve bilgi sahibi değil & 16 & 22,53 \\
\hline Projektif testler (Ağaçtan elma toplayan kişi, Good Enough, vb.) & 5 & 7,04 \\
\hline Grup terapisinin içerisinde yer verilmekte & 1 & 1,41 \\
\hline Seramik ve Resim Teknikleri ile Uygulamalar & 7 & 9,86 \\
\hline
\end{tabular}

Tablo 5 incelendiğinde katılımcıların büyük bir çoğunluğunun $-\% 50,7$ 'sinin ( $\mathrm{f}=36$ )- bu soruyu yanıtlayamadığ1 görülmüştür. Yanıt veren katılımciların çoğunun -\%22,53'ünün (f=16)- görsel sanatlar yoluyla tedavi hakkında birimlerinde bu tedavi yöntemini kullanmadığ1 ve bilgi sahibi olmadığ1 anlaşılmaktadır. Bu doğrultuda, araştırmaya katılanların oldukça büyük çoğunluğu - $\% 73,23$ ’̈ (f=52)- bu konu hakkında bilgi sahibi değildir ve bu soruyu yanıtlayamamıştır. Katılımcıların yanıtları arasında ikincil çoğunlukla \%9,86'sının ( $\mathrm{f}=7$ ) çalıştıkları birimlerde "seramik ve resim teknikleri ile uygulamalar" yaptırdıkları tespit edilmiştir. Sırasıyla \%7,04 (f=5) oranıyla "Projektif Testler" (ağaçtan elma toplayan kişi, 
Good Enough, ve TAT (tematik alg1 testi) olduğunu belirtmişlerdir) kullandıkları ve \%1,41 (f=1) oranıyla da "grup terapisi" içerisinde yer verildiği bulgulanmıştır.

d)Terapide Tercih Edilen Görsel Sanatlar Çalısmaları Hakkında Bulgular: Sağlık personelinin görüşleri doğrultusunda hastaların tedavisinde kullanılmak üzere tercih edilen görsel sanatlar çalışmaları önceliklerine göre belirlenmiştir. Katılımcıların ilk üç tercihlerine ait bilgi Tablo 6'da sunulmuştur.

Tablo 6. Hastalarn Tedavisinde Tercib Edilen Görsel Sanatlar Çalsşmalar

\begin{tabular}{lcccc}
\hline Kategoriler & 1. & 2. & 3. & Toplam \\
\hline Kil- seramik & 23 & 3 & 1 & 27 \\
Mozaik & 1 & 8 & 1 & 10 \\
Kolaj (Kes-Yapıştır faaliyetlerini içerir) & 6 & 7 & 6 & 19 \\
Sulu boya & 3 & 8 & 3 & 14 \\
Pastel Boya & 6 & 8 & 9 & 23 \\
Akrilik boya (Suyla temizlenebilir) & 3 & 4 & 4 & 11 \\
Yağlı boya (Kimyasal malzemeyle temizlenir) & 2 & 2 & 5 & 9 \\
Kara kalem & 5 & 6 & 10 & 21 \\
Oyun Hamuru & 4 & 4 & 6 & 14 \\
Diğer (Örgü) & 1 & - & - & 1 \\
Belirtilmemiş & 17 & 21 & 25 & \\
\hline
\end{tabular}

Tablo 6 incelendiğinde sağlık personellerinin görüşleri doğrultusunda, katılımcıların katılım oranının (27 kişi) en çok olduğu ve bu katılımcıların çoğunluğunun (23 kişi) birinci sırada tercih ettikleri görsel sanatlar çalışmasının "kil-seramik" olduğu görülmektedir. Katılımcıların, katılım oranıyla en yüksek ikinci sırada (23 kişi) yer alan görsel sanatlar çalışmasının "pastel boya" olduğu görülmektedir. Katılımcıların "pastel boya" çalışmasını ikincil yoğunlukta (6 kişi) ilk sıraya yerleştirdikleri tespit edilmiştir. Üçüncü sırada (21 kişi) ise "kara kalem" çalışmasının olduğu görülmektedir. Kara kalem tercihini, katılımcıların ortak katılım düzeyiyle istikrarlı olarak (5 kişi) üçüncü yoğunlukta ilk tercihlerine yerleştirdikleri görülmektedir. Katılımcıların katılım oranında dördüncü sırada (19 kişi) yer alan "kolaj" çalışması varken; katılımcıların kolaj çalışmasını ikincil yoğunlukta (6 kişi) ilk sırada tercih ettikleri görülmektedir. Katılımcıların katılım oranlarına göre sırayla; "sulu boya", "oyun hamuru", "akrilik boya", "mozaik" ve "yağlı boya" tercihlerinin olması katılımcılar arasında değişen oranlarla birlikte bu çalışmaların ilk tercihler arasında yer aldığı anlaşılmaktadır. Bunlara ek olarak, katılımcılar içerisinden resim ve örgünün "diğer" seçenek olarak belirtildiği görülmüştür.

(e)Görsel Sanatlar Yoluyla Tedavi Uygulamasının Etkililiğine IIlişkin Bulgular: Görüşs bildiren katılımcıların verdikleri cevaplar içerik analizi ile detaylı olarak incelenerek 11 kategori altında toplanmış ve sonuçlar Tablo 7'de sunulmuştur.

Tablo 7. Görsel Sanatlar Yoluyla Tedavi Uygulamasmm Etkililiğine İlişkin Görüsler

\begin{tabular}{|c|c|c|}
\hline Kategoriler & $\mathrm{f}$ & $\%$ \\
\hline Gerekli ve önemli bir yöntem olarak görüyorum. & 25 & 35,2 \\
\hline Destekleyici tedavi olarak kullanılması gerektiğini düşünüyorum. & 12 & 16,9 \\
\hline Uzman personel sayısı artırılarak yaygınlaştırılmalı & 5 & 7,04 \\
\hline Çocukların tedavisinde etkili olduğunu düşünüyorum & 4 & 5,6 \\
\hline Hasta motivasyonunu artırtmada etkili bir yöntem & 4 & 5,6 \\
\hline Hastanın kendini ifade etmesine yardımcı olmakta & 4 & 5,6 \\
\hline Hastalık sonrası takipte fayda sağlamaktadır. & 2 & 2,8 \\
\hline Grup terapilerinde daha etkili & 1 & 1,4 \\
\hline Hastanın tanınmasına yardımcı olmakta & 1 & 1,4 \\
\hline Negatif semptomlu hastalarda daha etkili & 1 & 1,4 \\
\hline Bilgi sahibi değilim (yorumlaması zor) & 7 & 9,8 \\
\hline
\end{tabular}

Tablo 7 incelendiğinde, sağllk personellerinin görsel sanatlar yoluyla tedaviyi büyük bir çoğunlukla $\% 35,2$ ( $\mathrm{f}=25$ ) "gerekli ve önemli bir yöntem" olarak düşündükleri görülmektedir. Katıllmmcıların ikincil çoğunlukta \%16,9'unun ( $\mathrm{f}=12$ ) ruhsal hastalıkların tedavisinde görsel sanatlar yoluyla tedavi yönteminin "destekleyici tedavi olarak" kullanılması gerektiğini düşündükleri tespit edilmiştir. Katıllımciların üçüncül çoğunlukta \%9,8’i ( $\mathrm{f}=7$ ) ise "bilgi sahibi olmadığını" ve "yorumlanmasını zor bulduğu" şeklinde düşündükleri tespit edilmiştir. Katılımcıların diğer bir çoğunluğunun $\% 7,04$ ’ü ( $\mathrm{f}=5)$ ise; "uzman personellerin artması ve uygulamanın yaygınlaşması" gerektiğini düşündükleri anlaşılmaktadır. "Çocukların tedavisinde daha etkili", "hasta motivasyonunu artırtmada etkili bir yöntem" ve "hastanın kendini ifade etmesine yardımcı olmakta" seçenekleri ise \% $\%, 6(\mathrm{f}=4)$ ile aynı oranda destekleyici bulunmuştur. "Hastalık sonrası takipte fayda sağlamaktadır" \%2,8 (f=2) desteklenirken, "grup terapilerinde daha etkili", "hastanın 
tanınmasına yardımcı olmakta" ve "negatif semptomlu hastalarda daha etkili" olduğu aynı oranda \%1,4 (f=1) katılımcı tarafından belirtilmiştir. Katılımcıların 12'si bu konu hakkında görüş bildirmemiştir.

f) Görsel Sanatların Tedavide/Terapide Kullanılmasına Yönelik Ë̆itimin İlgili Sağılk Personellerince Talep Edilme Durumunu ile ilgili bulgular: Bahsi geçen eğitimin talep edilme durumu incelenmiş ve sonuçlar şekil 2'te verilmiştir.

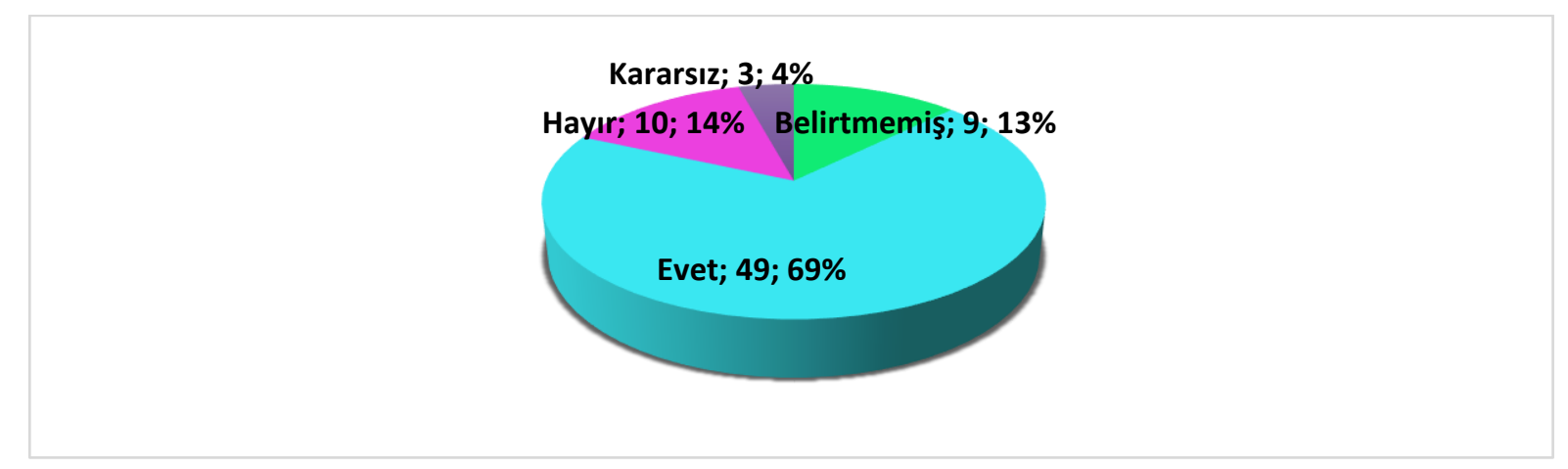

Şekil 2. Görsel Sanatlarn Tedavide/Terapide Kullanılmasına Yönelik. Eğitimin İlgili Sağhlk Personellerince Talep Edilme Durumu.

Şekil 2 incelendiğinde, katılımcıların büyük bir çoğunluğunun -\%69'unun ( $\mathrm{f}=49)$ - tedavilerinde kullanmak üzere görsel sanatlar eğitimi almayı talep ettikleri anlaşılmaktadır. Daha sonra sırasıyla \%13’ü $(\mathrm{f}=9)$ görüş belirtmezken; \%14'ünün ( $\mathrm{f}=10)$ bu eğitimi almak istemediği anlaşılmıştır. \%4'ünün ( $\mathrm{f}=3)$ ise bu eğitimi alıp almama konusunda kararsızlık yaşadığ1 görülmüştür. Araştırmaya katılan birçok sağlık çalşsanı, görsel sanatların tedavide/terapide kullanılmasına yönelik olan bir eğitime katılmayı olumlu olarak belirtmişlerdir.

\section{Tartışma}

\section{Alt Amaçlarla İlgili Yorumlar}

a) Psikiyatri Birimlerinde Görsel Sanatlar Yoluyla Tedavi (Terapi) Uygulamasının Varlığına İliskin yorum: Ak1l hastanelerinde belgelenen ilk sanat terapisi 1940'larda Washington'da bulunan St. Elizabeth Hastanesi'nde uygulandı (Ajmal, 2018, s. 11). St. Elizabeth Hastanesi ve Menninger Kliniği'nde olduğu gibi II. Dünya Savaşı'ndan sonra görsel sanatlar yoluyla tedavi (sanat terapisi), psikiyatri hastanelerinde ciddi akıl hastalığı olan hastalarda kullanılmaya başlandı (Serlin, 2007, s. 113). Aynı şekilde Wallace (2014) de; 1940’lar itibariyle sanatçlar ve sanat eğitimcileri tarafindan psikiyatri hastanelerinde hastalar için kolaylaştırılmışs sanat dersleri verilmeye başladığını belirtir. Konu ile bağlantılı olarak, birçok uzun süreli veya kronik psikiyatri servisinde 20. yüzyılın ortasından beri görsel sanatlar yoluyla tedavi (sanat terapisi), rutin bakımın bir parçası olarak görülmektedir (Chiu, Hancock ve Waddell, 2015, s. 34). Buna ek olarak, Avrupa'da da birçok psikiyatri kliniğinde uğraşı terapilerinin, görsel sanatlar yoluyla tedavi (sanat terapileri) gibi psikososyal uygulamaların ilaç tedavileri ile birlikte yürütüldügü bilinmektedir (Ergün vd., 2015, s. 34). Smeijsters ve Cleven (2006) ise Hollanda'nın sağlık bakım sisteminde, sanat terapilerinin, psikiyatri ve adli psikiyatride tedavinin düzenli bir parçası olduğunu ifade eder (s. 37). Bunlara ek olarak; Alberta Çocuk Hastanesi'nde hem yataklı hem de ayakta tedavi alan çocuklar ve onların ailelerinin faydalanacağı multidisipliner tedavi yaklaşımı uygulanmaktadır. Bu yaklaşım içerisinde geliştirilen çeşitli sanat terapötik etkinlikleri (görsel sanatlar, müzik, dans ve benzeri) vardır (Lind, Cantell, Baggott, Houde ve Coupal, 2015, s. 3).

Bu araştırmanın verileriyle de paralel şekilde Türkiye'de, Babaoğlu'ndan aktaran Demir (2018)'e göre görsel sanatlar yoluyla tedavi (sanat terapi) programları yatılı psikiyatrik rutinde ve psikosomatik kliniklerde uygulanmaktadır (s. 225). Buna ek olarak ruh sağlığı hastanelerinin bünyesindeki gündüz hastanelerinde belirtildiğine göre; çocuk, ergen, nevrozlu ve psikosomatik hastalarda olduğu gibi psikozlarda da etkili ve yardımcı bir tedavi yöntemi olan görsel sanatlar yoluyla tedavi hizmetleri uygulandığ1 (Güney, 2001, s. 273) anlaşılmaktadır. Utaş Akhan (2012) ise psikiyatri kliniklerinde, resimle ve diğer sanat dallarıyla çalışmanın, hastaların tedavi ve teşhis süreci ile hastalı̆ın gidişatının yorumlanmasında sağlık profesyonellerine; kendilerini ifade etme olanağı bulabilme açısından ise hastalara olumlu katkı sağlayacağını yapmış olduğu çalışmada belirtmiştir (s. 135). Bu konuda psikologların sanat çalışmaları alanında güçlendirilmesi 
gerektiğini vurgular ve güzel sanatlar eğitiminin klinik psikoloji eğitim sürecinde seçmeli dersler yolu ile yer almasını önerir (Yılmaz, 2017, s. 42). Bu görüşlerin paralelinde, yapılan çalışmaların, yaratıcı aktivitelerle uğraşmanın fiziksel ve ruhsal iyi olmayı sağladığı yönünde olduğunu; ruh sağlığı hizmetleri veren birimlere sanat terapisi hizmetlerinin sağlanmasını önermektedirler (Lamont, Sutton ve Brunero, 2009, s. 69). Salderay (2010)'in da belirttiği gibi sağlık alanında görsel sanatların alternatif tedavi yöntemleri içerisinde ele alınması, görsel sanatların tedavi (terapi) amaçlı kullanılmasına olanak sağlamaktadır. Shella (2018)'ya göre; psikoterapi yaklaşımında sanat eseri oluşturmanın, hastaları değerlendirirken duygusal ve fiziksel iyileşmeye katkı sağlayacağını belirtir (s. 59).

Bu noktada, hali hazırda ruh hastalığ1 sebebiyle hastanelerde yatan ya da ayakta tedavi alan hasta gruplarının tedavi aldığı sağllk kurumlarında görsel sanatlar yoluyla tedavi uygulamasının, düzenli bir tedavinin parçası olarak uygulandığı ya da çeşitli projelerle desteklenerek yapılmakta olduğu görülmektedir. $\mathrm{Bu}$ durumun, araştırmaya katılan sağlık personellerinin (klinik doktoru, asistanı, psikolog, hemşire ve / veya sosyal hizmet uzmanı) görüşlerinin oluşmasında etkili olduğu düşünülebilir. Görsel sanatlar yoluyla tedaviye ruhsal hastalıkların tedavilerinde teorik olarak yer verilmesinin, sağlık çalışanları tarafindan doğru bir yaklaşım olarak kabul edildiği söylenebilir. Ancak bu araştırma için yapılan başvuruda Ankara Hacettepe Üniversitesi Tip Fakültesi İhsan Doğramacı Çocuk Hastanesi ve Başkent Üniversitesi Ankara Hastanesi, görsel sanatlar yoluyla tedavi uygulamalarının yapılmadığını belirtmişlerdir. Bu doğrultuda psikiyatri birimlerinde görsel sanatlar yoluyla tedavi (terapi) uygulamasının literatürdeki önemine kıyasla bu durumun Türkiye'de daha az yer bulduğundan söz edilebilir. Bu duruma, sağllk personelinin uygulamaya yönelik gereklilikleri ve/veya sanatsal tekniklerin kullanılabildiği konusunda yeterli bilgiye sahip olmamaları rol oynayabilir.

b) Görsel Sanatlar Yoluyla Tedavinin Uzmanlık Alanına Yönelik Yorum: Ortaya çıkan sonuçtan hareketle, konu ile bağlantıll olarak alanda yapılan diğer çalışmaların bu araştırmayla paralellik içinde olduğu görülebilir. Bu doğrultuda; öncelikle tüm ruh sağlığı alanında çalışan doktorlar, psikologlar ve hemşirelerin aslında sanatın tedavi boyutuyla ilişkili (Greenstone, 2016, s. 806) olduğu söylenebilir. Malchiodi (1999) ise, sanatsal ifadenin tıp ortamında, özellikle çocuk hastalarla yapılan terapide; sanat terapistleri, oyun terapistleri, psikologlar, tıbbi sosyal hizmet uzmanlan, klinik danışmanlar, hemşireler ve diğer sağlık uzmanları tarafından yaygın olarak kullanıldığını belirtir (s. 13). Bu konuyla ilgili Phillips (2016) ise sanatın tedavi boyutunu içeren bir çalışmanın, birçok farklı alandan gelen uzmanların öncülüğünde yapılıp toparlanan profesyonel bir bölgeyi ortaya koyduğunu (s. 777) belirtir. Buna ek olarak, II. Dünya Savaşı sonrasında ortaya çıkan büyük ölçüde keşfedilmemiş bir alan olan görsel sanatlar yoluyla tedavinin (sanat terapisinin) alan sanat eğitimcileri, psikiyatristler, sanatçılar, danısmanlar, eğitimciler, rehabilitasyon, hemşirelik, sosyal hizmet ve benzeri diğer mesleklerin öncülüğünde (Phillips, 2016, s. 777) yapılandırıldığını belirtir. Bu görüşü destekler şekilde Hinz (2009), Amerikan Sanat Terapisi Derneği’ni farklı uzmanlık alanlarına sahip sosyal hizmet uzmanı, psikiyatrist, sanat eğitimci ve sanatçı gibi uzmanların bir araya gelerek kurduğunu belirtir (s. 21). Bugün ise, eğitimli sanat terapistleri ve terapötik sanat etkinlikleri sağlayan diğerleri arasındaki farklılıkların belirtilmesi çok daha zor olmaktadır (Rubin, 2010, s. 26). Kore'de yapmış oldukları araştırmada Park ve Hong (2010), ruh sağllğ̣ alanında çalışan sağlık personellerinin \% 83,4'ünün psikolog; \% 71,4'ünün sosyal hizmet uzmani; \% 30,3'ünün psikiyatrist ve \% 30 'unun hemşire olarak sanat terapisi uygulama deneyimine sahip olduklarını bulgulamıştır (s. 337). Bu araştırmada da görüldügü üzere birçok farklı uzmanlık alanının görsel sanatlar yoluyla tedavi konusunda ilgi sahibi olduğu anlaşılmaktadır.

Araştırmanın bulgularından hareketle katılımcılar; görsel sanatlar eğitiminin \%15,5'inin ( $\mathrm{f}=11$ ) hemşireler tarafindan verildiğini belirtirken; \%19,7 ( $\mathrm{f}=14)$ oranındaki katıllımcı ise görsel sanatlar yoluyla tedavinin hemşireler tarafindan verilmesi gerektiğini düşündükleri tespit edilmiştir. Bu konuyla alakalı Ergün ve diğerleri (2014) ise klinik aktivitelerde hemşirelerin sorumluluklarından birinin hastalara "resim yaptırmak" olduğunu belirtmişlerdir (s.19). Wiedenbach'e göre hemşireliğin sanat boyutu; hastaların gereksinimlerini ve kaygılarını anlamak ve hastaların yeterliliğini artıran amaçlar ve uygulamalarla hastayı geliştirmektir (Teksöz ve Ocakçı, 2014, s. 119). Bu doğrultuda özelikle çocukla iletişim kurarken çocukla hastanede çalışan tüm sağlık profesyonelleri gibi hemşireler de resim çizdirme yönetimi kullanabilir (Şen Beytut, Bolış1k, Solak ve Seyfioğlu, 2009, s. 36). Tracy vd. (2003)'nin yaptıkları araştırmada, alternatif ve tamamlayıc1 yöntemler içerisinde kabul ettikleri sanat terapisine, hemşirelik uygulamaları içerisinde yer verdiği anlaşılmaktadır (s. 201-208). Shorofi ve Arbon (2010), aynı konu üzerine yaptıkları çalışmada, hemşirelerin, -alternatif ve tamamlayıcı yöntemler içerisinde- sanat terapisi uygulamalarında az da olsa yer aldıklarını belirtmişlerdir (s. 230-231). 
$\mathrm{Bu}$ araştırmaya katılan sağlık personelinin görüşlerine göre \%5,6 (f=4) sosyal hizmet uzmanı görsel sanatlar yoluyla tedavi hizmeti sunmakta iken; katllımcilar \%15,5 ( $\mathrm{f}=11$ ) oranında sosyal hizmet uzmanlarının, bu alanla ilgilenilmesi gerektiğini düşündükleri görülmektedir. Bu görüşü destekler şekilde olan Greenstone (2016) da Amerika Birleşik Devletleri'nde yaptığı araştırmasının bulgularına göre; zihinsel sağlık alanında sanat terapisi hizmeti veren uzmanları -\%1 oranından daha azını- sanat terapistleri oluştururken; \%11,5'ni evlilik ve aile terapistleri; \% 28,8'ini profesyonel danışmanlar ve $\% 62,8$ 'lik büyük oranını da sosyal hizmet uzmanları oluşturmaktadır (s. 805). Bu doğrultuda, sanat terapisi öncülerinin içinde bulunduğu Amerika Birleşik Devletleri'nde bile çoğunlukla sosyal hizmet uzmanlarının bu alanda çalıştıkları anlaşılabilir. Buna ek olarak, Finlandiya, Almanya, Slovakya, Hırvatistan ve Slovenya gibi ülkelerde sanat terapisi, başka bir disiplin içinde -iyileştirici pedagoji (curative pedagogy) veya sosyal hizmet- uzmanlık olarak da çalışılmaktadır (d'Elia, 2016, s. 704). Bu konuyla bağlantılı olarak, sosyal hizmetlerin kapsamının ve faaliyet alanının oldukça geniş olduğunu belirten Hasgül (2016)'e göre sosyal hizmet eğitimi ve uygulamasında sanatsal duyarlılık, önemli bir değerlendirme ve müdahale aracıdır. Bu doğrultuda, sosyal hizmet uzmanlarının, hem kendileri hem de uygulamaları için ilgi duydukları bir alanda sanatsal bir tedavi aracını öğrenmeleri konusunda desteklenmesini önermektedir (s. 57-59). Tazeoğlu Erol (2016) ise, sosyal hizmet biliminin, uygulamalarının doğası gereği sanatsal etkinliğe yaklaştığını belirtmiştir. Mesleğin etkin bir pratik ortaya koymasında önemli gördüğ̈̈ bu sanatsal niteliğin, sanat ve bilimin bütüncül boyutunu ifade ettiğinden bahseder (s. 29). Belirtilenlere ek olarak, Özgür Sayar (2005)'a göre sosyal hizmet uzmanları, sanat terapisi eğitimi alarak klinik uygulamalarda bu yöntemi kullanabilecek bir meslek grubu (s. 133) olarak görülmektedir. Bu görüşler doğrultusunda, bütüncül bir yaklaşım içinde sanatın tedavi boyutunun, sosyal hizmet uzmanlarınca dikkate değer bir önem taşıdığından söz etmek doğru olur.

$\mathrm{Bu}$ araştırmanın verilerinde $\% 25,4$ ( $\mathrm{f}=18$ ) oranında görsel sanatlar öğretmenlerinin, mevcut durumda tedavi hizmetine destek olduğu görülürken; katılımciların \%36,6’s1 ( $\mathrm{f}=26)$ daha çok ilgilinin bu alanda çalışması gerektiğini düşündükleri anlaşılmaktadır. Bu konuyla ilgili, Salderay (2009)'a göre, görsel sanatlar eğitiminin tek amacı sanatsal olana ulaşmak değil; bireyin kendisine de ulaşabilmektir. Bu nedenle görsel sanatlar eğitimi, bireyin ihtiyacına cevap verecek nitelikte oluşturulan bir programı kapsamaktadır (s. 11). Bu görüş doğrultusunda, bireyin ihtiyaçlarına cevap verecek şekilde eğitim veren görsel sanatlar öğretmeni, tedaviye (terapiye) destek olabilir. Örneğin; Friedl Dicker-Brandeis, resmi olarak bir resim öğretmeni olsa da onun yaklaşımı, görsel sanatlar tedavi uygulamaları yaklaşımlarında görülebilen sonuçlara benzer sonuçlar vermiştir (Salderay, 2010, s. 136). Kramer ise sanat terapistiyle, sanat öğretmeni arasında çok az farklıllğın olduğunu belirtir. Birçok uzman da bu görüşe katılır. Terapide ürün önemli olduğu kadar; süreç de öğretime kıyasla önemlidir. Terapist, hastaya uygun terapötik bir program yapılandırması yapabilmesi için, hastaların özel ihtiyaçlarına sanat öğretmeninden daha fazla duyarlı olmalıdır (Ulman, 2001, s. 19). Konuyla bağlantılı olarak Rubin (2010)'e göre, hastaların sahip olabileceği çağrışımlardan biri de sanat derslerine benzeyen sanat terapisi seanslarıdır. Sanat terapisti, aktiviteyi yönlendirmek ve öğrenci ve/veya hastanın sanat eserini değerlendirmek için orada bulunan bir sanat öğretmeni gibidir (s. 25). Ancak, sanat materyallerinin uygun psikodinamik kullanımı, hastaların terapileri ve zihinsel durumlarını keşfedebilecekleri bir ilişkinin oluşmasını sağlar (Oustinova, 2017, s. 27-28).

$\mathrm{Bu}$ araştırmanın verilerinde $\% 8,4(\mathrm{f}=6)$ oranındaki sanat terapisi uzmanının, mevcut durumda tedavi hizmetlerine destek olduğu görülürken; sağlık personelinin görüşlerine göre bu oranın -\% $\% 50,7$ ( $\mathrm{f}=36$ )- daha çok olması gerekmektedir. Bu görüşü destekler şekilde Rubin (2010), sanatın iyileştirici gücünün bilinmesinin bazı konularda karışıklık yarattığını ifade eder. Hastanede yatan hastalara boyamada yardım eden biri, hemşire, gönüllü, sanatçı, öğretmen ya da sanat terapisti olabilirken; hastaların klinik uygulamalarında çizim yapmak veya yaratıcı görevler almak isteyen psikologlar, sosyal hizmet uzmanları, psikolojik danışmanlar ve psikiyatristlerin de olduğuna dikkat çeker. Ancak gönüllüler ve veya hemşireler, sanatı dikkat dağıtıcı olarak kullanmaktan öteye gidemezken; sanatçı ve/veya sanat eğitimcileri de psikolojik süreçlere müdahale edemeyebilir. Sanat terapistinin, psikoloji ve psikoterapide olduğu kadar; sanatta, yaratıcı anlayış ve başkalarına yardım etme konularında da eğitim alan bir uzman olduğuna dikkat çeker (s. 25-36). Aynı şekilde, D’Elia (2016) ise, Avrupa özelinde sanat terapisi eğitimi alabilmek için; güzel sanatlar, eğitim, psikoloji veya sosyal bilimler veya tıp alanında lisans derecesinin genellikle girişs şartı olarak arandığını belirtir (p.706). Buna ek olarak, sanat terapisi ve diğer sanat temelli aktiviteler ile sanat ögretmenleri veya uğraşı terapistleri tarafindan yürütülenler arasındaki farklılıklar daha da artmaktadır (Edward, 2004, s. 40). 
$\mathrm{Bu}$ araştırmaya katılan \%45 ( $\mathrm{f}=32)$ oranındaki sağlık personeline göre görsel sanatlarla tedavi uygulamasının, uzmanlardan oluşan bir ekip tarafindan verilmesi gerektiği tespit edilmiştir. Araştırma verilerinin paralelinde, Greenstone (2016) ise, sanat terapistlerinin diğer meslek grupları ile süreklilik ve iş birliği içinde olması gerekliliğini vurgular. Yaratıcı sanatlar, sağlık hizmetleri sürecinde giderek artan bir öneme sahip olmakla birlikte farklı eğilimlerde uyumluluk gösterir. Müttefik disiplinlerle birçok ortak noktaya sahip olmasının yanı sıra alana özgü farklllıklara da sahiptir (s. 805). Kar ve Toros (2015) ise sanat terapisinin, multidisipliner bir alan olduğunu; uygulamasında bir ekip ve iş birliği gerektirdiğini belirtir. $\mathrm{Bu}$ ekipte sanatçının yanı sıra psikiyatrist, psikolog, sosyal çalışmacı, çocuk gelişim uzmanı, nörolog, hemşire, rehberlik ve araştırma uzmanının da yer alabileceğini söyler (s. 194). Buna ek olarak, sanat terapisi, genellikle daha büyük bir hizmetin bir parçası olarak sağlandığından, bir sanat terapistinin işindeki önemli bir yönü; psikiyatristler, uğraşı terapistleri, hemşireler, sosyal hizmet uzmanları, öğretmenlerle iş birliği kurmaktır (Edward, 2004, s. 73). Bu noktada, Ciornai ve Ruiz (2016), profesyonel sanat terapistlerinin çalışmaları ve klinik ortamdaki diğer sanat kullanımları arasındaki sınırların her zaman net olmadığını ve sanat terapisi teriminin uygun bir ayrım yapılmadan kullanıldığını belirtir (s. 759). Buna ek olarak, Greenstone (2016), birçok müttefik gruba ait sanatın, kendi disiplinlerinde kullandığına (s. 808) dikkat çeker. Anand (2016) ise sanat terapistlerinin; ayakta tedavi klinikleri, rehabilitasyon merkezleri, evde sağllk kurumları, hastane merkezleri, geriatri (yaşlılık) tedavi tesisleri gibi kurumlarda; doktorlar, hemşireler, psikologlar, sosyal hizmet uzmanları, çocuk yaşamı uzmanlarıyla ilgili diğer sağlık profesyonellerinden oluşan ekibin bir üyesi olarak çalıştı̆̆ını ifade eder (s. 409). David (2016), sanat terapistleri de dahil olmak üzere sağılk çalışanlarının, tıbbı bir rahatsızlık geçiren hastanın sağlatımına yardımcı olduğunu belirtir. Hastaları sanat süreçlerine sokmak; sanatsal ifadeyle kendi sorunları ile başa çıkmayı yönlendirmede güçlü bir katk1 sağlar ancak bu durumun sağlık ekibinin diğer üyelerine de iletilebilmesi gerekmektedir. Diğer bir deyişle farklı disiplin yöntemleri veya mesleğin kendine özgü amaçları olabilir ancak ekip üyelerinin göstereceği disiplinler arası bir yaklaşım, sadece belirlenmiş klinik hedefleri gerçekleştirmekle kalmaz; bu yaklaşımın hasta açısından da fazlasıyla memnuniyet verici olacağını vurgular (s. 445). Bouchard (1998) ise sanat terapisine ortak güçlerle bir yaklaşımda bulunulmasıyla birlikte onun; demokratik ve saygıdeğer bir yöntem haline geldiğini ifade eder (s. 64). Buna ek olarak Greenstone (2016), hızla gelişen sağlık sistemlerinde devamlllı̆̆ sağlayabilmek için aynı düşünce yapısına sahip diğer meslek gruplarıly iş birliği içinde çalışmanın önemli olduğunu belirtir (s. 808). Bu görüşleri desteklerce Salderay (2014a)'in da belirttiği gibi görsel sanatlar yoluyla tedavinin, disiplinler arası bir yaklaşımla yürütülebileceğini ve tüm rehabilitasyon (iyileştirme) uygulamalarında olduğu gibi uzman bir kadro ile sağlıklı uygulanabileceğinden bahseder (s.12). Buna ek olarak sanat terapisti uzmanlık alanının, Türkiye'de devlet onaylı bir eğitim programı olmadığı bilinmektedir. Bu konuda Özgür Sayar (2005), Türkiye'de görsel sanatlar yoluyla tedavi (sanat terapisinin) eğitimi olmadığını ve insana yardım meslekler olarak sınıflandırdığı psikolog, rehber, psikolojik danışman ve sosyal hizmet uzmanlarının bu konu ile yeterince ilgili olmadığını (s. 132) belirtmiştir. Ancak sanat terapisi uzmanları ve Türkiye'de yetişmiş bile olsa sanat terapistleri, tıp alanında yer alacaksa bunun tıbbi ortamları, hastalar ve hastalık durumları hakkında mümkün olduğunca bilgi edinmeleriyle ve diğer tedavi hizmetleriyle disiplinler arası çalışma anlayışı geliştirilerek sağlanmalıdır; diğer bir ifadeyle uzmanlardan oluşan bir ekiple birlikte, tıp dünyasıyla sanat dünyası arasında ortak bir iletişim dili içinde olmalıdırlar (David, 2016, s. 443). Bu doğrultuda, görsel sanatlar yoluyla tedavi için bireyin tedavisinde terapinin ana bileşeni olmasa bile disiplinler arası yaklaşımla birlikte önemli bir parçası olabileceği (Greenstone, 2016, s. 808) söylenebilir.

Yukarıda değinildiği üzere, sağlık alanında hizmet veren uzmanların uzmanlık alanları ve disiplinleri gereği görsel sanatlarla bağlantılı olduğu görülmüştür. Bu araştırmaya katılan sağlık personellerinin görüşlerinin çoğunluğu, alanda yapılan çalışmalarla bağdaşmaktadır. Bu duruma, sağlık çalışanlarının görsel sanatlar ve görsel sanatlar eğitimi ile ilgili olumlu bakış açıları ve/veya inançları, görüşlerin oluşmasında rol oynayabilmiştir. Ancak, tek bir uzmanlık alanının bu konuda eğitim verebileceğini düşünen görüşlerin aksine alanda yapılan çalısmalardan anlaşılacağı gibi farklı disiplinlerdeki görsel sanatların, insan sağlığını ilgilendiren konulardaki birleştirme çabaları görülmektedir. Sağlık çalışanlarının bu görüşlerinin oluşmasında, mevcut bilgi düzeyi ile birlikte ön yargılarının rol oynadığı düşünülebilir. Bu doğrultuda hem sanat hem de sağlık terapi alanında eğitim alan sanat terapistlerinin bu disiplinleri birleştirmesinde büyük öneme sahip olduğu görülebilir. Ancak, Türkiye'de bu uzmanlık alanına dair eğitim veren bir devlet onaylı bir kurum henüz bulunmamaktadır ve konuyla ilgili literatür incelendiğinde sanat terapi uzmanı olsa bile sağlık çalışanlarından oluşan bir ekiple çalışılmasının daha doğru olduğu söylenebilir. Bu düşünceden hareketle görsel sanatlar yoluyla tedavi uygulamalarının sağlık alanında kullanılmasının ancak alan 
uzmanlarından oluşan bir ekiple, disiplinler arası iş birliği yaklaşımının benimsenmesiyle doğru bir yaklaşım olabileceğinden bahsedilebilir.

c) Görsel Sanatlar Yoluyla Tedavi Uygulamasında Kullanılan Yöntem ve/veya Tekniklere İlişkin Yorum: Katılımcıların bu konuyla ilgili görüşleriyle birlikte, konuda yapılmış çalışmalar incelendiğinde bu soruya yanıt veren katılımcıların görüşlerini destekleyen sonuçlar görülmüştür. $\mathrm{Bu}$ doğrultuda, sanat terapisi farklı bir tedavi yönteminden ziyade; bir beceri veya teknik olarak görülür. Bunun bir nedeni de diğer meslek gruplarından, (psikiyatristler, hemşireler, sosyal hizmet uzmanları, uğraşı terapistleri vb.) sanatın tanılama ve tedavi amacıyla kullanılmasıdır (Edward, 2004, s. 4). Araştırmaya katılan sağlık personelinin görüşlerine göre \%7,04 (f=5) oranında projektif (yansıtmacı) testlerin ilgili birimlerde kullanıldığı anlaşılmıştır. Bu doğrultuda öncelikli olarak psikoloji biliminin projektif (yansıtmacı) testleri kullandığı gibi projektif (yansıtmacı) çizimler olarak adlandırdığı çizimlerden de tanı ve teşhiste faydalandığ belirtilmelidir. Bu testlerde, kişiden çizim yapması istenerek testi alan kişinin sanat üretimine girmesi istenir ve eğitimli uygulayıcı tarafından yorumlanır (Yılmaz, 2017, s. 34-36). Bu konuyla ilgili Naumburg (1958)' a göre resimsel yansitma (projeksiyon) yoluyla terapi, psikanalitik prosedürde sanatsal bir yöntem-teknik tercihidir. Hasta ve terapist arasında sembolik iletişim kurar. Sanatsal olarak eğitilmiş olsun veya olmasın bütün bireyler gizli bir kapasiteye sahiptir. Hastaların resimleri, onlar hakkında veriler edinilmesini sağlar; fantezileri, hayalleri, korkuları, çatışmaları ve çocukluk anıları iç çatışmalarını görsel biçimde yansıtır (s. 343). Aynı konuyla ilgili Hinz (2009) ise; değerlendirme amaçlı çizim yaptıran psikologlar, çizimleri sanattaki bağlamlarından çıkararak puanlama sistemleri ile formüle etiklerinden bahseder. Ayrıca bu uzmanların projektif (yansıtmacı) çizimlerdeki kesin göstergelere odaklandığın; psikiyatrik belirtiler veya bozukluklarla belirli grafik işaretlerini eşleştirmeye çalıştıklarını belirtir (Hinz, 2009, s. 191). Ancak, psikiyatrik bozukluklar homojen veya statik koşullar olmadığından, projektif (yansıtmacı) çizim tekniklerinin güvenilirlik ve geçerlilik çalışmalarından elde edilen sonuçlar değişkenlik göstermiştir. Buna ek olarak, sanat terapistlerinin sanatın iyileştirdiği sezgisel bilgisini desteklemek için kanitlar üretmesi daha da önemlidir (Slayton, D’Archer ve Kaplan, 2010, s. 108). Bu doğrultuda, her insanın farklı olduğu gibi hastalıkları ve etkileri de farklı olabileceği için; projektif testlerin güvenirliliği hakkında kesinlik olmadığından bahsedilebilir.

Bu araştırmaya katılan sağlık personeli arasında bir katılımcının "grupla terapi" seanslarında görsel sanatlar yoluyla tedavi tekniklerini kullanıldığını belirtmiştir. Bu doğrultuda Waller (2003)'e göre; grup çalışması, birçok farklı sağık ve sosyal hizmet kuruluşunda tedavinin merkezinde yer almaktadır. Birbirine bağlı ağlar yelpazesinde karmaşık olan grup etkileşimli sanat terapisi modelinden ise; sosyo-kültürel konuya vurgu yaparak sözlü ve görsel iletişim ve kişisel olduğu kadar politik bağlamda anlayış için ümit verici bir yaklaşım olarak söz etmektedir (s. 313-323).

Araştırmaya katılan sağlık personelinin görüşlerine göre; \%8,45 ( $f=9$ ) oranında birimlerinde uğraşı terapileri ve diğer terapilere yer verildiği görülmüştür. Bu doğrultuda, sanat terapisinin terapötik uygulamalarının sıklıkla yanlış anlamalara neden olacak şekilde karıştırıldığı meslek grubu, uğraşı (occupational) terapisidir. Bunun iki ana nedeni vardır: İlkine tarihsel olarak bakıldığında sanat terapisi ve uğraşı terapisinin birbirlerine bağlı olmasıdır. Bir süre sanat terapisi bölümleri, uğraşı terapisi bölümleri içerisinde yer almış ve sağlanan genel hizmetin bir parçası olmuştur. İkincisi ise uğraşı terapisi sanatının teşhise yardımcı olarak projektif tekniklerle tedavi edici bir yöntem olarak zihinsel sağlıkla ilgili uzun süredir kullanıyor olmasıdır (Edward, 2004, s. 5). Uğraşı terapi mesleği geleneksel olarak çeşitli aktivitelerle uygulanmaktadır. Faaliyetlerin seçimi, hasta gruplarına bağlı olarak terapötik kullanımında değişiklik göstermektedir. Zihinsel alanda ise sıklıkla, esnekliği nedeniyle tedavi programına en iyi adapte olan hastanın değişken modu ve ihtiyaçlarını karşılayabilecek sanat içerikli aktiviteler seçilmektedir (Lloyd ve Papas, 1999, s. 31). Bu konuyla ilgili Edward (2004) ise, genel olarak bir sanat terapistine göre uğraş1 terapistlerinin sanata çok daha az önem vermeye eğilimli olduğundan söz eder. Ayrıca sanat terapisinde ürün ve sürecin birbiriyle bütünleştiğini; oysaki uğraşı terapisinde bitmiş sanat eserlerinin genellikle ikincil öneme sahip olarak kabul edildiğine dikkat çeker (Edward, 2004, s. 6). Bu araştırmanın verilerinden de anlaşıldığ üzere uzmanların hala bir kısmının sanat terapisi ve uğraşı terapisi ayrımında karışıklık yaşadığ1 düşünülebilir. Uğraşı terapisi ve sanat terapisinin sanat kullanımları arasındaki farkları incelemesi ve netleştirilmesi, iki disiplinin ortak sınırları çerçevesinde belirlenmesinin ihtiyaç durumu olduğu söylenebilir. Sanat terapisi olarak bahsedilen kavramın sıklıkla görsel sanatlar yoluyla tedavi için kullanıldığı görülebilir. Bu konuyla alakalı Edward (2004)'a göre; sanat terapisinde görsel sanatlara (öncelikle resim, çizim ve heykel) odaklanılan bir ilişki olduğunu not etmek gerek ve bu ilişki genellikle müzik, drama veya dans gibi diğer sanat türlerinin kullanımını içermez (s. 3). Ancak, sanat kavramı gibi sanat terapisi kavramının da 
içerisinde görsel sanatlar yoluyla tedavinin de dahil olduğu müzik terapi, dans ve hareket terapisini vb. içine alan bir üst başlık olarak kabul edildiğinden bahsedilebilir.

$\mathrm{Bu}$ araştırmaya katılan sağlık personelinin görüşlerine göre \%9,86 ( $\mathrm{f}=7$ ) oranında "seramik ve resim teknikleri ile uygulamalar" birimlerinde kullanılan görsel sanatların yöntem ve/veya teknikler arasında olduğu bulgulanmıştır. $\mathrm{Bu}$ doğrultuda; Naumburg resim ve kil modelinin analitik psikoterapideki avantajlan için ilk olarak rüyaların; fantezileri ve diğer içsel yaşantıları ifade etmede sözcüklerden ziyade daha başarılı olduğunu; ikincisinin ise bilinçaltının materyal kullanımıla sansürsüz bir şekilde ifade edilebilmesini belirtmiştir. Özellikle resim ve kil modelinin bu sebeplerden dolay1 psikanalizle veya terapinin analitik yönüyle yakın ilişkili olduğunun altını çizer (Ulman, 2001, s. 17- 18).

Yukarıda söz edildiği üzere sağllk personelinin görüşlerine göre görsel sanatlar yoluyla tedavi uygulamalarında kullanılan yöntem ve tekniklerin belirlenmesi amaçlanmıştır. Bu doğrultuda, araştırmaya katılan sağlık personelinin büyük çoğunluğunun bu soruyu yanıtsız bıraktığı ve bilgi sahibi olmadığ1 görülmüsstür. Görsel sanatlar eğitimi tekniklerinin kullanılabildiği konusunda bilgi sahibi olmamaları, bu konuyla ilgili görüsslerini belirtmemelerindeki etken olduğu düşünülebilir. Bununla birlikte, görsel sanatlar yoluyla tedaviyi bir yöntem ya da teknik olarak diğer terapi yöntemleri ve yansıtmacı (projektif) testler içerisinde gördükleri anlaşılmaktadır. Farklı meslek gruplarında tanı ve teşhis amaçlı kullanılan bu testlerin sağlık personelinin bu konuyla ilgili görüşlerini oluşturmasında etkili olduğu söylenebilir. Ayrıca, küçük bir oranda sağlık personelinin mevcut bilgileri içinde görsel sanatlar yoluyla tedaviye yönelik resim ve seramik teknikleri olduğu görülebilir. Bu doğrultuda, sağlık personelinin görsel sanatlarla tedavide uygulanabilecek yöntem ve teknikler anlamında desteklenmesinin (eğitim almasının) faydalı olacağı söylenebilir. Bu görüşü destekler şekilde; Salderay (2013) tarafından yapılan çalışmada psikiyatri bölümlerinde çalışan sağlık personellerinin görsel sanatlar ile terapinin bağıyla ilişkin bilgilerinin olduğunu; ancak görsel sanatlar yoluyla tedavi uygulamasıyla ilgili bilgilerinin daha az olduğu sonucuna varmıştır (s. 199-211). Bu sebeple, bu birimlerde çalsşan sağlık personelinin konuyla ilgili bilgilerinin tazelenmesi ve uygulamaya yönelik desteklenmesinin gerekliliğinden söz edilebilir.

d) Terapide Tercih Edilen Görsel Sanatlar Çalısmaları Hakkında Yorum: Landgarten (1981), iki ve üç boyutlu sanat formlarından her ikisinin de sıklıkla hastaların gizli duygulan, düşünceleri veya çalışma şekli hakkında somut kanıtlar sunduğunu belirtir. Tedavi ortamlarında ise en çok kullanılanların; yağlı pastel boyalar, keçeli kalemler, suluboyalar, akrilik boyalar, hamur, kil, kağıt mendil ve dergi resimleri olduğunu belirtir (s. 4). Pénzes vd. (2014), sanat terapisi değerlendirmesine farklı yaklaşımlar geliştirilmesi ve sanat materyallerinin merkezi bir rol oynaması gerektiği konusunda hemfikirdirler. Bununla birlikte, farklı sanat materyallerinin rolü konusunda nispeten az araştırma yapıldığına dikkat çekerler. Hinz (2009) ise; her türlü malzemenin duygusal tepkiyi uyandıracak şekillerde kullanılabileceğini; ancak genel olarak etkili bir terapötik yaklaşım için hastanın materyalleri ve konuyu serbestçe seçmesine izin verilmesinin gerekliliğini belirtir (s. 108). Buna ek olarak, Pénzes vd. (2014), hastanın, sanat malzemelerinin belirli özellikleriyle (yani, materyal etkileşimi) etkileşimde bulunma şeklinin, hastanın zihinsel sağlığının yönlerini yansıttığını vurgular. Bu bilginin ise daha kaliteli bir tedavi sunma, tedavi hedeflerini formüle etme ve uygun sanatsal müdahalelerini seçmede ya da karar almada yardımcı olduğuna dikkat çekerler (s. 484). Buna ek olarak, Edward (2004) ise sanat terapisinin öncelikle birine terapötik uygulama yapılmasıyla ilgili olduğunu ve bu terapötik uygulama içerisine resim, çizim veya heykel gibi görsel sanatların ve daha fazlasının eklenebileceğini belirtir (s. 6). Pesso-Aviv vd. (2014) ise, 7-9 yaş aralığındaki çocuklarla yaptıkları araştırmada, yağlı pastel, guaj boya ve kurşun kalemin farklı etkilerini incelemişlerdir. Materyallerin etkileri arasında çok büyük fark bulamamalarına rağmen guaj boyanın saldırganlık seviyesini diğer materyallere göre daha çok düşürdüğ̈̈ bulgulanmıştır. Bunun bir nedeni olarak da çocukların bu materyalle kurşun kalem ve yağlı pastelden daha az karşılaştıkları olduğu düşünülmüş̧ür (s. 293-300). Aynı konuyla ilgili Snir ve Regev (2013) de yaptığı çalışmada farklı sanat malzemelerinin farklı terapötik potansiyelleri olduğu sonucuna ulaşmıştır. Sanat materyali ile faaliyet, aslında malzemenin nitelikleri ve özellikleri ile sanatçının kişiliği arasındaki etkileşimin ve bu materyal ile önceki karşılaşma anılarının bir sonucudur. Hastaların kaotik (karmakarışı) bir iç gerçeklikleri olması nedeniyle kontrol edilebilecekleri materyallere ihtiyaçları vardır (s. 99). Pesso-Aviv vd. (2014), sanat terapisinde kullanılan eşlerin, terapi odasında "konuşulan dil" olduğunu belirtmiştir. Materyallerin kullanılmasıyla bu dilde düzenlenen diyalog; hasta ile iç dünyası arasında bir büyüme firsatı, ikilemlere çözüm bulma yeteneği, artan farkındalık potansiyeli ve iç deneyimlerin keşfedilmesini sağlar (s. 293). Aynı konuda Snir ve Regev (2013) ise; materyallerin yardımıyla oluşturulan diyalogun, içsel deneyimlere bir pencere yaratığını belirtir (s. 94). Bunların yanı sıra; hastaların çeşitli sanat malzemeleri (1slak ve kuru ortamlar, farklı türlerde kağıt, kil ve diğer üç boyutlu çalışmalar) 
içerisinden kendi materyal seçimini yapabilmesinin özel bir önemi vardır. Ayrıca, sanat malzemelerini nasıl kullandığı diğer bir deyişle farklı çalışma biçimleri, (yavaş, hızlı, dağınık, tekrarlayan, vb.) terapisti için hastanın şu andaki zihinsel durumunun bir göstergesi olabilir (Edward, 2004, s. 90). Bu görüşlerin paralelinde, Hinz (2009) ise dişa vurumcu terapi sürecinin bilişsel birleşenlerinin; soyut düşünce, planlama, sıralama ve problem çözme işlemlerini gerektirdiğini belirtir. Bilişsel bileşenlerle çalışmanın ise bilişsel becerilerin gelişimini arttırdığını vurgular. Bu doğrultuda, yapılandırmayla ilgili doğası olan materyallerin; ahşap, mozaik, elişi kağıdı ve kolaj bilişsel fonksiyonlanı tamamlama ve iyileştirmeye destek olacağına dikkat çeker (s. 142).

Katılımcıların katılım oranının ( $\mathrm{f}=27$ kişi) en çok olduğu ve bu katılımcıların çoğunluğun birinci sırada önemli gördükleri görsel sanatlar çalışmasının "kil-seramik" olduğu anlaşılmıştır. Bu konuda alanda yapılmış çalışmaların da bu araştırmanın sonuçlarını destekler nitelikte olduğu görülmektedir. $\mathrm{Bu}$ doğrultuda, 1995 yılında sanat terapistlerinin sanatsal medyayı kullanma tercihlerinin araştırıldığı çalışmada, katılımcıların \%99’u kil kullanımını terapötik olarak nitelendirmiştir (Sherwood, 2004, s. 1). Kimport ve Hartzell (2015) tarafindan yapılan araştırmaya göre; 49 hasta üzerinde sanat terapisi içerisinde kil uygulanmasının kaygı durumlarında ciddi azalmaya neden olduğu bulgulanmıştır (s. 184). Konuyla ilgili Rabiger (1990) ise; kilin özellikle çocuklarda el becerisini teşvik etmek için de iyi bir yol (s. 27) olduğunu vurgular. Buna ek olarak dokunsal medyanın, duygusal tepkileri canlandırması muhtemeldir, kil veya diğer benzer çalışmalarda rahatlama durumu için elverişli olduğu düşünülür (Oustinova, 2017, s. 22). Françoise Dolto; kağıt, kalem ve boyanın dışında heykel ve hamurla çalışmanın çocukların kendisini ifade etmesinde kullanılabileceğini ifade etmiştir. Bir şeye biçim vermek zaten çocuğun doğal olarak kendisini ifade etme şeklidir (Kamac1, 2004, s. 99). Salderay (2014a) ise psikiyatrik anlamda sıkıntı yaşayan çocukların tedavisinde, görsel sanatlar uygulamalarından sıklıkla yararlanıldığına dikkat çekerek hamur/kil çalışmalarının da bu kapsamda değerlendirildiğini belirtir. Bununla birlikte, hamur ve/veya kil içerikli çalışmaların; herhangi bir yaş kısıtlaması içermediğini bireysel ya da grup olarak uygulanabilmesi konusunda avantajları olduğunu belirtir (s. 7). Bu konuyla ilgili Henley (2002) ise çocuk için özellikle de özel ihtiyaçları olan çocuklar için, bu tür faaliyetlerin katkıda bulunduğunu belirtir. Çağın getirdiği yapaylık içerisinde çocuklar arasında doğal bir malzeme olan kilin, bir çekiciliği vardır. Kilin, zengin duyusal deneyimler uyandırarak hiperaktif (aşırı hareketli), ruhsal sıkıntısı olan ve/veya şımarık olarak tabir edilen çocuklarda bile olumlu yönlendirici etkisi olduğunu belirtir (s. 13). Malzeme seçiminde ve tercihinde bireysel farklılıkların da çok önemli rol oynadığından bahsedilebilir.

Sanat terapisinde kullanılacak sanat türü, tekniği ve malzemeleri, uygulanacak kişinin yaşı, mental (zihinsel) ve fiziksel gelişimi ve yeteneği ile uyumlu olmalıdır. Buna örnek olarak, Malchiodi’ye göre; kız çocukları resim yaparken karışık malzemelerle yapılan çalışmalarda üstünlük göstermekte iken; Gardner'in araştırmasına göre, erkek çocukları kil veya tek malzemeli görevlerde daha başarılıdır. Bu bağlamda, danışan birey için en uygun sanat tekniğine ve malzemesine karar verilmesi gerektiği söylenebilir (Malchiodi, 2013, s. 244). Bu görüşün paralelinde; sanat yapmanın bireylerin duyguları üzerinde önemli etkileri olduğu göz önüne alınırsa sanat terapisi seanslarında kullanılacak malzeme ve tekniğin katılımcının ruhsal savunma mekanizmalarını koruyacak şekilde seçilmesinin de önemi anlaşılabilir. Diğer bir deyişle, katılımcıya uygun olmayan malzeme ve teknik seçimi; hayal kırıklı̆g ile geri çekilmeye neden olabileceği gibi kişinin ajitasyonunun (aşırı huzursuzluk hali) artmasına da etken olabilir (Kar ve Toros, 2015, s. 194). Bunun yanı sıra aynı sanatsal etkinlikler aynı malzemelerle bile farklı bireylerde ve/veya hasta gruplarında olumlu ya da olumsuz psikolojik etkiler ortaya çıkarabilir. Bu noktada, daha önce de sıkça bahsedildiği gibi uzman bir kadroyla çalışılmasının önem arz ettiği söylenebilir.

Yukarıda değinildiği gibi alan literatürü incelendiğinde sağlık alanında çalışan birçok uzman görsel sanatların içinde yer alan "seramik-kil" çalışmalarının hastalar üzerinde olumlu katkısı olduğu konusunda görüş belirtmişlerdir. Bu araştırmaya katılan sağlık personelinin görüşlerine göre de ilk sırada ve en çok tercih ettikleri "kil- seramik" çalışmalarının olduğu; bu görüşlerinin oluşmasında mevcut bilgi birikimi ve alanda edindikleri tecrübelerin etkili olduğu düşünülebilir. Buna ek olarak, farklı sanat materyallerin farklı terapötik etkileri olduğu düşünülmektedir ve bununla ilgili sınırlı da olsa veri bulunmaktadır. Bu çalışmaların araştırmaya katılan sağlık personelinin görüşlerinin bu yönde oluşmasında rol oynadığı düşünülebilir. Ancak, görsel sanatlar yoluyla tedavide farklı materyallerin terapötik etkileri üzerinde henüz oldukça az sayıda araştırma yapıldığı için bu materyallerle hastalar ile nasıl çalışıldığı ile ilgili araştırmaların da yapılmasına ihtiyaç olduğu görülebilir. 
(e) Görsel Sanatlar Yoluyla Tedavi Uygulamasının Etkililiğine İlişkin Yorum: Bu doğrultuda, sağlık çalışanlarının görsel sanatlar yoluyla tedavi uygulamasının etkililiğine ilişkin görüşlerinin alanda yapılan çalışmalarla uyum içinde olduğu görülebilir. Araştırmaya katılan sağlık çalışanlarının çoğunluğu bu uygulamanın "gerekli ve önemli" olduğunu ve "destekleyici tedavi” olarak kullanılması gerektiğini düşünmektedir. Bu bağlamda, Botton ve Amstrong'a göre (2014) sanatın ruhsal dengeyi yeniden sağlamadaki işlevi açısından önemli olduğundan bahseder. Landgarten (1981) ise; sanat psikoterapisinin sözsüz yönünün, zihinsel sağlık çalışmaları alanında önemli ve benzersiz bir yere sahip olduğunu belirtir çünkü terapistin, hastalarına gözleri ile dinleme firsatı vereceğinden bahseder (s. 4). Aynı konuyla ilgili Hinz'e göre (2009) hastaların sanat deneyimlerinin, duygularını isimlendirmelerinin, aralarında ayrım yapmalarının ve duygusal yıkım ya da tehdide maruz kalmadan güvenli bir şekilde duygu iletme yönteminin kendilerini ifade etmelerini sağladığına vurgu yaparak görsel sanatlar yoluyla tedavinin hastalar için önemine dikkat çeker (s. 120). Bu görüşü desteklerce Rubin (2010) ise psikanalitik klinisyenler tarafindan sanat terapisinin tedavide önemli bir ifade biçimi olarak kullanıldığını belirtir (s. 47). Ayrıca, bu araştırmada görsel sanatlar yoluyla tedavi uygulamasının destekleyici olarak kullanılabileceği görüşü yüksek oranda katlımcı tarafindan belirtilmiştir. Salderay (2014b) ise, görsel sanatlar eğitiminin, farklı konu alanları ile kolayca kaynaştırılabileceğinden, el-göz-beyin koordinasyonunu geliştireceğinden ve başarı duygusunu artıracağ1 gibi birçok sebepten dolayı önemli rolü olduğundan bahsetmektedir (s. 98-99). Bu konuda, araştırmaya katılan sağlık personeli de rehabilitasyonun; iletişim becerilerinin arttırılması, el-göz koordinasyonunun sağlanması ve yeti yitiminin kazandırılmasında kullanılabileceğini belirtmişlerdir. $\mathrm{Bu}$ görüşü destekler şekilde Salderay (2009); sanat eğitimi çalışmalarında kullanılan farklı malzemelerin, öğrencilerin el-göz eş güdümünün gelişmesine önemli ölçüde katk1 sağladığına vurgu yapar (s. 92). Hinz (2009) ise sanat terapisinin, işleme ve karar vermede bir tür bilgiyi aşma ya da kullanma eğiliminde olan bir bireyin işleyişini dengelemeye yardımcı olabileceğine dikkat çeker (s. 36). Buna ek olarak, görsel sanatlar ruh hastalıklarının tedavilerine destekleyici tedavi olarak kullanılırken; görsel sanatların alanında uzman kişilerce klinik uygulamalar ile birlikte yapılması gerektiği belirtilmiştir. Bu yaklaşım disiplinler arası bir yaklaşımı gerektirdiğinden dolayı tüm rehabilitasyon (iyileştirme) uygulamalarında olduğu gibi konu, özellikle uzman bir kadro ile sağllklı yürütülebilmektedir. Aksi takdirde; profesyonellikten uzak bir kadro ile bu tür bir uygulamaya girilmesi, sanatımsı denemeler yapılmasından öte bir durumu ortaya çıkarmamaktadır (Salderay, 2014a, s. 7). Bu görüşü destekler şekilde Rubin (2010), sanatın derin anlayışını ve yaratıcı sürecinin; psikoloji ve psikoterapi gibi eşit derecede karmaşık bir anlayışla birleştirmenin gerekli olduğundan bahsetmektedir (s. 26).

Ruh sağlığ1 alanında görsel sanatlar yoluyla tedavinin etki alanlarını ifade edilen görüşler de; "çocukların tedavisinde etkili olduğu", "hasta motivasyonunu artırdığı", "hastalık sonrası takipte faydalı olduğu", "grup terapilerinde daha etkili olduğu", "negatif semptomlu hastalarda etkili olduğu" ve "hastanın tanınmasında yardımcı olduğu" şeklindedir. Belirtilen görüşlerin alanda yapılmış çalışmalarla bağdaştı̆̆ görülmektedir. Bu doğrultuda, Landgarten (1981)'e göre; psikiyatri hastanesi ortamında, sanat terapisi gruplar1 genellikle bireylerin ve grubun gücünü ortaya koymak için tematik olarak yönlendirilir (s. 6). Liebmann (2003)'a göre; bazı durumlarda, bireysel veya grup sanat terapisi kullanma seçeneği vardır. Sosyal öğrenmenin çoğu gruplar halinde yapıldığı için bu durum sosyal becerileri geliştirmede destek olur, karşılıklı problem çözme ile benzer ihtiyaçları olan insanlar birbirlerine karşılıklı destek sağlayabilir ve yardım edebilir. Bu doğrultuda grup çalışmasında sanat terapisinin kullanılması iyi bir bağlam sağlar. Buna ek olarak, gruplara bir aidiyet ve kimlik duygusu sağlar. Temalı bir grup, üyelerin belirli konulara farklı açılardan bakmalarına yardımcı olabilir. Temaları uygun bir şekilde kullanmak, hem sanat terapisinde hem de belirli bir grubun ihtiyaçları konusunda bilgi ve beceri gerektirir (Liebmann, 2003, s. 326-338). Ayrica, duygusal açıdan kırılgan hastalar için, özellikle yansıtıcı uzaklığ1 kurma ve yalnızca sanatı duygulardan arındırmak yerine iletişim kurmak için kullanma becerisine yardımcı olmak da son derece terapötik olarak nitelendirilmektedir (Hinz, 2009, s. 109). Bunlara ek olarak, araştırmaya katılan sağlık personellinin görüşleriyle bağlantılı olarak çocuk hastaların bu uygulamalarda daha çok faydalanılabileceğinin düşünüldüğü görülmekte ve alandaki çalışmaların da aynı görüşü desteklediği görülebilir. Bu doğrultuda, duygusal ve davranışsal rahatsızlık belirtileri gösteren çocuklara yardım için; genellikle kliniklere, özel okullara, psikologlara ve aile doktorlarına başvurulur. Duygusal ve davranısssal problemler genellikle birbirleriyle bağlantılıdır ve çocuğun deneyiminin her iki yönü de birlikte çalışılmalıdır. Sanat terapisinde çalışmanın en önemli yönlerinden biri, sanat malzemelerinin kullanılmasının, çocuklara mücadele ettikleri zorlukların birçoğundan sözel olmayan bir çalışma biçimi sunmalanıdır (Case ve Dalley, 1992, s. 8). Psikoterapide sanata en sık başvurulan alan çocuk hastalarının terapi sürecidir. Çocuklarla terapi sürecinin zorlukları düşünüldüğünde, sanatın bu alanda kullanımının katkıları yadsınamaz (Kamac1, 2004, s. 99). Bu görüşleri destekler nitelikte, özellikle fiziksel olarak hasta çocuklarla yapılan sanat terapisi, onların umut 
yaratıcı sanat yaratma sürecini uygulamalarına yardımcı olmaktadır Çocuk ve terapist materyalleri seçmek, hedefler koymak ve bunları elde etmek için araçları planlamak için birlikte çalışıllır. Bitmiş ürün, hasta çocuğun başarabildiğinin somut kanıtıdır. Bu tür bir başarı, hasta çocuğun pasif bir halden kurtularak aktif bir ortağa dönüşmesine yardımc1 olur (Councill, 2003, s. 213). Buna ek olarak, sanat eseri ise, daha sonra bilinçli ve anlaşılabilir hale getirilebilecek güçlü duygular ve durumlar için güvenli bir ifade aracı olarak kullanılabilir. Az sayıda çocuk, duygularını ve altta yatan zorluklarını açıkça ifade edebildiği için, sanat ortamı onlara sözel olmayan şekilde tehdit edici olmayan bir ortamda keşfetme firsatı sunar (Case ve Dalley, 1992, s. 9). Ball (2002), yaptı̆̆ çalısmada; çocuk ve sanat arasındaki etkileşimlerin sistematik analizini içerir. Bu doğrultuda, çalışmaya katılan çocuğun altı ay içinde travmatik deneyimleri işleyişinde önemli değişiklikler olduğunu ortaya koymakla beraber bu çocuğun hem duygu ve dürtülerini düzenlemesi hem de kendini gözlemlemesi için kelime ve imajlardaki deneyimini sembolize etme yeteneğinde bir artış olduğunu bulguladı (s. 91). Belirtilenlere ek olarak, Güney (2011)'e göre, sanat eseriyle onu yaratan sanatç1 arasında; algısı, edindiği bilgi, tutum, davranış ve becerilerin tümü üzerinde bir ilişki vardır. Bu sebeple, insan bir sanat eserine bakarken (hatta bu sanatçının kendisi de olabilir), duygusal ifadeden etkilenir (s. 37). Malchiodi (2013) ise, resmin; kişisel dışavurum, bireyin bir uzantısı, düşünce ve duyguların görülebilir yansıması olduğunu belirtir (s. 75). Bu konuyla ilgili Shella (2018), sanat terapistlerinin -psikoterapi yaklaşımı olarak- hastaların sanatsal çalışma oluşturması ve hastaları değerlendirmesinin yanında hastaları duygusal ve fiziksel iyileşmeye teşvik ettiğinden bahseder (s. 59). Sanat psikoterapisi yaklaşımı ile psikanalitik terapi yakından uyumludur. Bilinç dışı süreçler yoluyla imge ve çizim, hastayla terapist arasındaki aktarımın sağlanımında oldukça önemli rol oynar (Coşkunlu, vd., 2018, s. 20). Bu bağlamda, hastanın kendini ifade etmesinde uzmanlara takip sağlamasında görsel sanatlar yoluyla tedavinin yardımcı olduğu düşünülebilir.

Yukarıda değinildiği üzere sağlık personellerinin genel olarak olumlu ifadeler belirtikleri bu durumun, görsel sanatlar yoluyla tedavinin faydalı olacağına dair geliştirdikleri inançlardan kaynaklandığ1 düşünülebilir. Ayrıca, sağlık personelinin, görsel sanatlar alanına kişisel ilgileri ve/veya deneyimleri, görüşlerinin olumlu oluşmasına etki etmiş olabilir. Buna ek olarak sağlık personeline göre, görsel sanatlar yoluyla (tedavi) uygulamasının, birçok alanda etkili olduğu anlaşılmaktadır. Bu durumda farklı alanlardan (çocuk/yetişkin) katılan uzmanların kendi uzmanlık alanları doğrultusunda değerlendirmesinin rol oynadığ1 düşünülebilir. Bununla birlikte; sağlık çalışanlarının, hastaları yordama yönlerinin gelişmesinde ve terapötik fayda sağlamada görsel sanatlar tekniklerinin kullanıldığından haberdar olmamaları veya bu konuda yeterli bilgiye sahip olmamalarının da diğer görüşlerin oluşmasında etkili olduğu söylenebilir.

f) Görsel Sanatlatın Tedavide/Terapide Kullanılmasına Yönelik Ĕ̈itimin İlgili Sağhlk Personellerince Talep Edilme Durumunu ile ilgili yorum: Bu konuda yapılmış çalışmalar incelendiğinde de sağlık çalsşanlarının görüşlerini destekleyen sonuçlar görülmüştür. Bu doğrultuda, Rubin (2010)'e göre, tüm terapi biçimlerinde olduğu gibi, görsel sanatlar yoluyla tedavi/terapide, (sanat terapisinde) anlama ve sentezin sadece deneyim ile elde edileceğine vurgu yapar (s. 27). Aynı konuda Malchiodi (2013), resim malzemelerinin nasıl kullanıldığını, terapistin de bilmesinin önemli olduğunu belirtmiş ve eğer terapist resim malzemelerini tanımaz ve ne işe yaradıklarını bilmez ise yeterli talimatlarda bulanamayacağına dikkat çeker. Buna ek olarak, resim sürecinin kişisel deneyim gerektirdiğini vurgular ve sözel anlatımın bu bilgileri yeterince veremeyeceğini belirtir (s. 56). Rubin (2005b) ise, psikiyatri kliniğinde çalışan psikiyatristler, psikologlar ve sosyal hizmet uzmanları tarafindan görsel sanatların nasıl kullanıldığına dair bir eğitim talep edildiğini belirtir. Psikologlar bazında düzenlenen bu eğitimin sosyal hizmet uzmanları tarafindan da istendiğini vurgular (s. 4). Konuya ilişkin Rubin (2005a), farklı yaş gruplarının ana temalarını anlamaya yardımcı olmak için çocuk psikologlarına, psikiyatristlere ve diğer klinisyenlere verilen eğitimin faydalı olduğunun ispatlandığını belirtir (s. 55). Bu konunun paralelinde çocuklarla yapılan terapiye dikkat çeken Malchiodi (2013) ise terapinin veya değerlendirmenin bir parçası olarak çocuklardan resim çizmelerini isteyen pek çok terapistin, çocuk hastalar tarafindan yaratılan resim anlatımlarını nasıl ele alacakları konusunda eğitilmemiş olduğundan bahseder (s. 284). Oustinova (2017) ise terapistin görevinin yalnızca hastanın durumuna, sınırlamalarına ve gelişim düzeyine duyarlı olmak olmadığını; aynı zamanda, sanat materyalleriyle etkileşiminin de nasıl bir şey olduğuna dair empatik bir kavrayışa sahip olabilmesini belirtir (s. 9). Bu noktada, terapistin çizim sürecinin neyi gerektirdiğini tam olarak anlaması çok önemlidir. Elbette ki çizimi anlamak için en iyi yol; ilk elden tecrübe etmektir. Resimleri, görsel sanatlarla ilgili bilgi birikimi olmadan okumaya çalışmak; insanları izleyerek yani yalnızca gözlemleyerek onların deneyimlerinin nasıl bir şey olduğunu anlayabileceğini düşünmektir ve tecrübeyi tam olarak anlamak için bizzat deneyimlemeyi gerektirmektedir (Malchiodi, 1998, s. 26). Görsel sanatlar 
yoluyla tedavi eğitiminin sağılk personellerince alınmasının somut katkısına yönelik olarak Malchiodi (2013), resim yapmanın, olumlu ve sağlatıcı bir deneyim olabilmesi için öncelikli olarak terapistin, resim yapmanın çocuğun bunalımlarına sağlıklı çözümler getireceğine ve çocuğa yardımcı olacağına dair ikna olması gerektiğini belirtir (s. 78). Aynı şekilde, çocuklarda olduğu gibi yetişkinlerde de görsel sanatlar yoluyla tedavinin faydalı olacağına öncelikle sağlık personelinin ikna olmasının gereğinden bahsedilebilir. $\mathrm{Bu}$ doğrultuda sağlık personeline, görsel sanatların tedavide/terapide kullanılmasına yönelik bir eğitim ile bilgi ve donanım düzeyi artırllarak konuyla ilişkin olumlu tutumlar kazandırılacağından söz edilebilir. $\mathrm{Bu}$ görüşü destekler şekilde Rubin (2010), bir sanat terapistinin öncelikli olarak sanat bölümünü anlaması; daha sonra materyaller, yaratıcı süreçler ve sanatsal ürünler hakkında çok şey bilmesi gerektiğinden bahseder (s. 74). Bu görüşü destekleyen Malchiodi (2013) de sadece psikolojik yönlerin değil; zaman içinde çocukların resimle anlatımları arasındaki resim yapma sürecinin, malzemelerin ve değişimlerin de bilinmesinin gereğinden bahseder. Resim terapisi alanındaki araştırmacılar; son zamanlarda yansıtıc1 resimlerde olan belli maddeleri, elemanları veya resim yapma sürecini ve malzemeyi -dışarda bırakmak yerine- etki yapısal nitelikler aracilığıyla resimleri anlama yollarını araştırmalıdır (s. 42). Bu noktadan hareketle doğru bir tedavi yaklaşımının belirlenebilmesi için, sanat materyallerinin sunumunda, yaratma sürecine rehberlik etme (yardımcı olma) ve bu sürecin sonucunda çıkan sanat eserinin korunmasını sağlama; bu tedaviyi uygulayacak uzmanların dikkat etmesi gerektiği özelliklerdir. Görsel sanatlar yoluyla tedaviyi kullanacak uzmanların sanat materyalleriyle birlikte tekniklerini tanımaları ve neler yapılabileceğine ait kişisel deneyimlere sahip olmaları etkili bir tedavi için önem arz eder. Rubin (2011)'e göre; temel sanatsal malzeme türleri, gerçekte sayıca azdır; ancak her birini derinlemesine bilmek gerekir (s. 7). Bu görüşü destekler şekilde Oustinova (2017) ise, sanat malzemelerini bilmenin bir sanat terapisti için çok önemli olduğunu belirtir (s. 19).

Yukarıda belirtildiği gibi, sağılk personellerinin görsel sanatların tedavide/terapide kullanılmasına yönelik eğitime katılmayı talep eden görüşlerinin, alanda yapılmış çalışmalarla bağdaşmasının yanında; görsel sanatlar eğitimine yönelik olumlu bakış açılarının da bu görüşlerin oluşmasında etkili olduğu düşünülebilir. Bununla birlikte olumsuz ve kararsız olarak görüş belirten sağlık personelinin görsel sanatlar tekniklerinin tedavi amaçlı kullanımında yeterli bilgiye sahip olmamalarının da görüşlerinin oluşmasında etkili olduğu söylenebilir. Ek olarak sağlık personelinin yoğun hasta yükü sebebiyle kendilerini farklı bir alanda geliştirecek zaman bulamaması da bu konudaki görüşlerinin olumsuz olmasında rol oynadığ1 söylenebilir.

\section{Sonuç}

\section{Araştırmanın Bulgularına Dayalı Olarak Aşağıdaki Sonuçlara Ulaşılmıştır:}

Çalışmaya katılan sağlık personelinin (klinik doktoru, asistan, psikolog, hemşire ve/veya sosyal hizmet uzmanı) görüşleri doğrultusunda; (a) görsel sanatlar yoluyla tedavi uygulamasının psikiyatri birimlerinin \%49'unda yapıldığı; (b) bu uygulamanın hali hazırda sağlık personelleri arasından farklı meslek grupları tarafindan verildiği; ancak $\% 36$ oranılla sanat terapi uzmanı ve $\% 32$ oranıyla uzmanlardan oluşan bir ekip tarafindan verilmesinin daha uygun görüldüğ̈̈; (c) kullanılan yöntem ve/veya tekniklere ilişkin \%73,23 oranla yanıt verilemediği ve/veya bilgi sahibi olunmadığı ancak; (d) "kil-seramik" çalışmalarının alanlarında en etkili uygulama, ve (e)\%35,2 oranıyla uygulamanın "gerekli ve önemli bir yöntem olarak" görüldüğü olarak görüldüğ̈̈; sonucuna varılabilir. (f) Ayrıca çalışmaya katılan sağlık personelinin (klinik doktoru, asistanı, psikolog, hemşire ve/veya sosyal hizmet uzmanı); \%69 oranında -büyük çoğunluğunun- görsel sanatların tedavi/terapi olarak kullanımına yönelik eğitim talep ettiği ihtiyaç durumu olarak görüldügü sonucuna varlabilir.

\section{Öneriler}

\section{Uygulamaya Yönelik Öneriler:}

1. Sağlık personellerinin görsel sanatlar yoluyla tedavi uygulamalarında kullanılmak üzere öğretim teknikleri ve uygulama çalş̧maları konusundaki mevcut bilgi ve becerileri, hizmet içi eğitim faaliyetleri ile geliştirilmelidir.

2. Araştırma sonuçlarına dayalı olarak uzman görüşleri doğrultusunda hastane ortamında ideal bir görsel sanatlar yoluyla tedavi atölyesi oluşturulmalı ve hastane ortamına yapılacak atölyelerde bu atölye örnek alınmalıdır.

3. Psikiyatri birimlerinde görsel sanatlar yoluyla tedavi atölyesi kurulmalı; varsa uzman görüşleri doğrultusunda tedavi atölyeleri yeniden düzenlenmelidir. 
4. $\mathrm{Bu}$ araştırmadan elde edilen sonuçlar Sağlık Bakanlı̆̆ının ilgili birimleri tarafından değerlendirilmeli ve uygulamalarda kullanılmalıdır.

\section{İleri Araştırmalara Yönelik Öneriler:}

Bu alanda çalışmak isteyen araştırmacılara;

1. Benzer bir araştırmanın farklı bir ilde sağılı personelini kapsayacak şekilde uygulanması,

2. Benzer bir araştırmanın, sadece doktorların görüşleri alınarak çalısılması,

3. Benzer bir araştırmanın ara sağlık elamanlarının (hemşire, psikolog vb.) görüşleri alınarak çalışılması,

4. Benzer bir araştırmanın psikiyatri birimlerini kullanan hastaların bakış açlarıyla birlikte görsel sanatlar yoluyla tedavi durumunun etkililiğinin araștırılması,

5. Benzer bir araştırmanın çocuk hastanelerini kapsayacak şekilde uygulanması önerilebilir.

\section{Etik Beyan}

"Hastanelerin Psikiyatri Hiæmetlerinin Sunulduğu Birimlerde Görsel Sanatlar Ë̈itiminin Tamamlaync Tedavi Olarak Uygulanabilirliğine İlişkin Durumun İncelenmesi" başlıklı çalışmanın yazım sürecinde bilimsel kurallara, etik ve alıntı kurallarına uyulmuş; toplanan veriler üzerinde herhangi bir tahrifat yapılmamış ve bu çalışma herhangi başka bir akademik yayın ortamına değerlendirme için gönderilmemiştir. Gerekli olan etik kurul izinleri Gazi Üniversitesi Klinik Olmayan Araştırmalar Etik Kurulu'nun 23.10.2017 tarih ve 493 sayllı toplantısında alınmıştır.

\section{Teşekkür}

Tezime doktora araştırma projesi olarak destek sağladığı için Gazi Üniversitesi Bilimsel Araştırma Projeleri (BAP) Birimi'ne teşekkür ederim. TÜBİTAK 2211-A Yurt İçi Doktora Burs Programı'na tezime ve doktora sürecime destek olduğu için teşekkür ediyorum.

\section{Kaynakça}

Ajmal, M. (2018). Effectiveness of art as therapy for ptsd and depression Pakistan (Master's Thesis). Yaşar University Social Sciences Institute, İzmir.

Anand, S. A. (2016). Dimensions of art therapyin medical illness. In D. E. Gussak \& M. L. Rosal (Eds.), The Wiley Handbook of Art Therapy (pp. 409-420). USA: Wiley-Blackwell.

Ball, B. (2002). Moments of change in the art therapy process. The Arts in Psychotherapy, 29(2), 79-92.

Botton, A. ve Armstrong, J. (2014). Terapi olarak sanat (Çev: V. Atmaca). İstanbul: Everest.

Bouchard, R. R. (1998). Art therapy and its shadow: A Jungian perspective on professional identity and community. Art Therapy, 15(3), 158-164. doi.org/10.1080/07421656.1989.10759318

Case, C. ve Dalley, T. (1992). The handbook of art therapy. New York: Brunner-Routledge.

Chiu, G., Hancock, J., ve Waddell, A. (2015). Expressive Arts Therapy Group Helps Improve Mood State in an Acute Care Psychiatric Setting (Une thérapie de groupe ouverte en studio basée sur les arts de la scène améliore l'humeur des patients en psychiatrie dans un établissement de soins intensifs). Canadian Art Therapy Association Journal, 28(1-2), 34-42. doi.org/10.1080/08322473.2015.1100577

Ciornai, S., ve Ruiz, M. C. (2016). Latin american art therapy: Collective dreams and horizons of hope. In D.E. Gussak \& M.L. Rosal (Eds.), The wiley handbook of art therapy (pp. 753-764). USA: Wiley-Blackwell.

Cohen, L., Manion, L., ve Morrison, K. (2007). Research methods in education. New York: Routledge.

Coşkunlu, A., Tanıl, E., Coffey, A., Büyüktaşkın, D., ve Mulligan, A. (2018). The Vasarhelyi method of child art psychotherapy: an adjunctive treatment in childhood depression. Psychoanalytic Psychotherapy, 32(1), 19-39. doi.org/10.1080/02668734.2017.1334150

Councill, T. (2003). Medical art therapy with children. In C. A. Malchiodi (Ed.). Handbook of art therapy (pp. 207-219). New York, London: The Guilford.

David, I. R. (2016). Art therapy in medical settings. In D.E. Gussak \& M.L. Rosal (Eds.), The wiley handbook of art therapy (pp. 443-450). Malden, USA: Wiley-Blackwell.

d'Elia, M. (2016). Art therapy in europe. In D.E. Gussak \& M.L. Rosal (Eds.), The wiley handbook of art therapy (pp. 701-709). Malden, USA: Wiley-Blackwell

Demir, V. (2018). Sanatla terapi programının bireylerin kaygı, sosyal kaygı ve sağllk kayg1sı düzeyleri üzerine etkisi. Uluslararası Sosyal Bilimler Dergisi, 1(2), 223-234. Erişim adresi: https://dergipark.org.tr/en/download/article-file/523445.

Edward, D. (2004). Art therapy. London: Sage.

Ergün, G., Işı1k, I. ve Dikeç, G. (2015). Ülkemiðdeki Psikiyatri Kliniklerinin Tedavi Edici Ortam Yönünden İncelenmesi. (Proje No-VKV 2014-4), Burdur: Vehbi Koç Vakfi. Erişim adresi: https://sanerc.ku.edu.tr/wp- 
content/uploads/2017/04/\%C3\%9Clkemizde-Psikiyatri-Kliniklerinin-Tedavi-Edici-OrtamY\%C3\%B6n\%C3\%BCnden-\%C4\%B0ncelenmesi.pdf

Frank, J. D. (1985). Psychiatry The State of The Art: Psychotherapy and Psychosomatic Medicine.(Vols.4). S. P1chot, S. Berner, R. Wolf, \& K. Thau (Eds.), Shared Therapeutic Features of Psychotherapies (pp.1-7). New York \& London: Plenum.

Gönülay Çalımlı, Z. (2014). Alternatif tedavi yöntemleri içerisinde kullanulan görsel sanatlarn kemoterapi alan hastalarn kayg düzeylerine etkisi (Yüksek Lisans Tezi). Gazi üniversitesi Eğitim Bilimleri Enstitüsü, Ankara.

Greenstone, L. (2016). Issues in credentialing and licensing for art therapy in the united states: Who ate my pie? In D. E. Gussak \& M. L. Rosal (Eds.), The wiley handbook of art therapy (pp.802-813). USA: John Wiley \& Sons.

Güney, M. (2011). Sanat ve Psikiyatri. Ankara: Öz Baran.

Hasgül, E. (2016). Sosyal hizmet uygulamalarında sanatın önemi. International Journal of Innovative Research in Education, 3(2), 55-60. doi.org/10.18844/ijire.v3i2.998

Henley, D. (2002). Clayworks in art therapy: Plying the sacred circle. London, England: Jessica Kingsley.

Hinz, L. D. (2009). Expressive therapies continuum: A framework for using art in therapy. Routledge.

Kamacı, B. (2004). Süleyman Velioğlu ve akatünvel sanat topluluğu bağlamında psikiyatri ve sanat iliskisisi. (Yüksek Lisans Tezi). Mimar Sinan Güzel Sanatlar Üniversitesi Sosyal Bilimler Enstitüsü, İstanbul.

Kar, Ö., ve Toros, F. (2015). Aile içi şiddet ve çocuk istismarı olgularında sanat terapisi. Hacettepe Üniversitesi Sağhlk. Bilimleri Fakültesi Dergisi, 1(2), 192-211. Erişim adresi: https://dergipark.org.tr/en/download/article-file/88858.

Kimport E. R., ve Hartzell, E. (2015) Clay and anxiety reduction: a one-group, pretest/posttest design with patients on a psychiatric unit, Art Therapy, 32(4), 184-189. doi:10.1080/07421656.2015.1092802

Kinney, J.M. ve Rentz, C.A. (2005). Observed well-being among individuals with dementia: Memories in the Making, an art program, versus other structured activity. American Journal of Alzheimer's Disease and Other Dementias, 20(4), 220-227.

Lamont, S., Sutton, D., ve Brunero, S. (2009). A brief report of art therapy in an in-patient mental health unit: Consumer feedback and experience. Australian and New Zealand Journal of Art Therapy, 4(1), 68-74.

Landgarten, H. B. (1981). Clinical art therapy: A comprehensive guide. New York: Routledge

Liebmann, M. (2003). Developing games, activities, and themes for art therapy groups. . In C. A. Malchiodi (Ed.). Handbook of art therapy (pp. 325-338). New York, London: The Guilford.

Lind, C., Cantell, M., Baggott, S., Houde, M. \& Coupal, S. (2015) Participatory action research with therapeutic arts practitioners: research capacity building in a pediatric hospital (recherche-action avec des praticiens des arts thérapeutiques : renforcement des capacités en recherche dans un hôpital pédiatrique), Canadian Art Therapy Association Journal, 28(1-2), 3-11. doi.org/10.1080/08322473.2015.1083642

Lloyd, C., ve Papas, V. (1999). Art as therapy within occupational therapy in mental health settings: A review of the literature. British Journal of Occupational Therapy, 62(1), 31-35. doi.org/10.1177/030802269906200109

Malchiodi, C. A. (1998). Understanding children's drawings. New York: The Guilford Press.

Malchiodi, C. A. (1999). Medical art therapy with children. London, Philadelphia : Jessica Kingsley.

Malchiodi, C. A. (2005). Expressive Therapies. New York and London : The Guilford Press.

Malchiodi, C.A. (2013). Cocuklarn resimlerini anlamak (Çev: T. Yurtbay). İstanbul: Nobel Tip.

Oğuz, N. Y. (2001). Tip etiğinin 1şı̆̆ında psikoterapi. Anadolu Psikiyatri Dergisi, 2(1), 36-40. Erişim adresi: https://search.proquest.com/openview/d19f2e876a227377c3ab258bf0d7b626/1?pqorigsite $=$ gscholar\&cbl $=136214$.

Oustinova, I. (2017). How art materials influence therapeutic alliance in psychodynamic art therapy with children in elementary schools (Master's Thesis). Erişim adresi: https://spectrum.library.concordia.ca/982224/1/Oustinova_MA_S2017.pdf

Özgür Sayar, Ö. (2005). Sanat ve insana yardım. Toplum ve Sosyal Hižmet, 16(2), 121-134. Erişim adresi: https://dergipark.org.tr/en/pub/tsh/issue/48440/613641.

Park, K., ve Hong, E. (2010). A study on the perception of art therapy among mental health professionals in Korea. The Arts in Psychotherapy, 37(4), 335-339. doi.org/10.1016/j.aip.2010.07.004

Pénzes, I., Van Hooren, S., Dokter, D., Smeijsters, H., ve Hutschemaekers, G. (2014). Material interaction in art therapy assessment. The Arts in Psychotherapy, 41(5), 484-492. doi.org/10.1016/j.aip.2014.08.003

Pesso-Aviv, T., Regev, D., ve Guttmann, J. (2014). The unique therapeutic effect of different art materials on psychological aspects of 7-to 9-year-old children. The Arts in Psychotherapy, 41(3), 293-301. doi.org/10.1016/j.aip.2014.04.005

Phillips, J. (2016). Identity of the Art Therapist. In D.E. Gussak \& M.L. Rosal (Eds.), The wiley handbook of art therapy (pp. 777-786). Malden, USA: Wiley-Blackwell.

Rabiger, S. (1990). Art therapy as a container. In C. Case \& T. Dalley (Eds.), Working with children in art therapy (pp.2338). London: Routledge.

Rubin, J.A. (2005a). Child art therapy. New Jersey: John Wiley \& Sons.

Rubin, J.A. (2005b). Arfful therapy. New Jersey: John Wiley \& Sons.

Rubin, J. A. (2010). Introduction to art therapy sources \& resources. New York: Routledge.

Rubin, J.A. (2011) The art of art therapy: What every art therapist needs to know. New York: Routledge.

Sağllk Bakanlığı (2011). Ulusal Rub Sağhğ Eylem Plam (2011-2023). Erişim adresi: https://www.psikolog.org.tr/doc/ulusal-ruh-sagligi-eylem-plani.pdf. 
Salderay, B. (2009). Türkiye'deki zibin engelliler iș okullarnnda görsel sanatlar dersinin ögrrencilerin beceri, davranıs ve meslek edinimindeki katkısına yönelik ögretmen görï̈leri (Doktora Tezi). Gazi Üniversitesi Eğitim Bilimleri Enstitüsü, Ankara.

Salderay, B. (2010). Görsel sanatlar ve tedavi. Gazi Üniversitesi Sanat ve Tasarm Dergisi, 1(6), 133-145. Erişim adresi: https://dergipark.org.tr/en/pub/sanatvetasarim/issue/20661/220416.

Salderay, B. (2013). Gazi Üniversitesi tıp fakültesi ruh sağlığı ve hastalıkları anabilim dalı ile Kahramanmaraş Necip Fazıl Şehir Hastanesi psikiyatri birimlerinde çalışan sağlık personelinin görsel sanatların terapi boyutuna ilişkin bilgi yapılanmaları. Uluslararası Türk ve Dünya Kültüründe Kabramanmaraş Sempozyumu bildirileri 2, 199-219.

Salderay, B. (2014a). Sanatla kendimi kesfediyorum hamur-kil çalşmalarmm eğitim ve rehabilitasyon boyutu. Ankara: Eğiten.

Salderay, B. (2014b). Özel eğitim sürecinde görsel sanatlar uygulamalarının önemine ilişkin aile düşünce yapılarının değişimi. Manas Sosyal Araștırmalar Dergisi, $3 \quad$ (11), 87-101. Erişim adresi :https://dergipark.org.tr/en/pub/mjss/issue/40491/485045.

Serlin, I. (2007). The arts therapies: Whole person integrative approaches to healthcare. Whole person healthcare, 3, 107121.

Erişim

adresi: https://www.researchgate.net/profile/Ilene_Serlin/publication/232462192_Theory_and_practices_of_art_the rapies_Whole_person_integrative_approaches_to_healthcare/links/5788738c08ae95560407c0b2.pdf

Shella, T. A. (2018). Art therapy improves mood, and reduces pain and anxiety when offered at bedside during acute hospital treatment. The Arts in Psychotherapy, 57, 59-64. doi.org/10.1016/j.aip.2017.10.003

Sherwood, P. (2004). Healing art of clay therapy. Australia: Acer Shorofi, S. A., \& Arbon, S. (2010). Nurses' knowledge, attitudes, and professional use of complementary and alternative medicine (CAM): a survey at five metropolitan hospitals in Adelaide. Complementary therapies in clinical practice, 16(4), 229-234. doi.org/10.1016/j.ctcp.2010.05.008

Shorofi, S. A., ve Arbon, S. (2010). Nurses' knowledge, attitudes, and professional use of complementary and alternative medicine (CAM): a survey at five metropolitan hospitals in Adelaide. Complementary therapies in clinical practice, 16(4), 229-234. doi.org/10.1016/j.ctcp.2010.05.008

Slayton, S. C., D'Archer, J., ve Kaplan, F. (2010). Outcome studies on the efficacy of art therapy: A review of findings. Art therapy, 27(3), 108-118. doi.org/10.1080/07421656.2010.10129660

Smeijsters, H., ve Cleven, G. (2006). The treatment of aggression using arts therapies in forensic psychiatry: Results of a qualitative inquiry. The arts in psychotherapy, 33(1), 37-58. doi.org/10.1016/j.aip.2005.07.001

Snir, S. ve Regev, D. (2013). A dialog with five art materials: Creators share their art making experiences. The Arts in Psychotherapy, 40(1), 94-100. dx.doi.org/10.1016/j.aip.2012.11.004

Sönmez, V. ve Alacapınar, F. (2014). Örneklendirilmiş bilimsel araștırma yöntemleri. Ankara: Anı.

Şen Beytut, D., Bolışık, B., Solak, U., ve Seyfioğlu, U. (2009). Çocuklarda hastaneye yatma etkilerinin projektif yöntem olan resim çizme yoluyla incelenmesi. Maltepe Üniversitesi Hemsirelik Bilim ve Sanatı Dergisi, 2(3), 35-44. Erişim adresi: http://openaccess.maltepe.edu.tr/xmlui/handle/20.500.12415/3585\#sthash.ijlNxTHV.dpbs

Tazeoğlu Erol, H. (2016). Bir bilim olarak sosyal biæ̧metin sanatsal yönü ve bir sanat olarak sinema ilişkisi (Yüksek Lisans Tezi). Başkent üniversitesi Sağlık Bilimleri Enstitüsü, Ankara.

Teksöz, E., ve Ocakçı, A. F. (2014). Çocuk hemşireliği'nde sanat uygulamaları. Dokuz Eylül Üniversitesi Hemşirelik Yüksekokulu Elektronik $\quad$ Dergisi, $7(2), \quad 119-123 . \quad$ Erişim adresi: https://dergipark.org.tr/en/pub/deuhfed/issue/46808/586999.

Tracy, M. F., Lindquist, R., Watanuki, S., Sendelbach, S., Kreitzer, M. J., Berman, B., ve Savik, K. (2003). Nurse attitudes towards the use of complementary and alternative therapies in critical care. Heart \& Lung: The Journal of Acute and Critical Care, 32(3), 197-209. doi:10.1016/S0147-9563(03)00040-2

Ulman, E. (2001). Art therapy: Problems of definition. American Journal of Art Therapy, 40(1), 16. Erişim adresi: https://search.proquest.com/openview/5f30d913bee588b81602931a09dd1dcf/1?pqorigsite $=$ gscholar\&cbl $=40839$.

Utaş Akhan, L. (2012). Psikopatolojik sanat ve psikiyatrik tedavide sanatın kullanılışı. Journal of Higher Education \& Science/Yüksekögretim ve Bilim Dergisi, 2(2), 132-135. doi.org/10.5961/jhes.2012.043

Wallace, N. (2014). The history of group art therapy with adult psychiatric patients (Master's Thesis). Erişim adres: https://scholarworks.iupui.edu/bitstream/handle/1805/4476/ThesisNatalieWallace.pdf?sequence=1\&isAllow $\mathrm{ed}=\mathrm{y}$

Waller, D. (2003). Group art therapy: An interactive approach. In C. A. Malchiodi (Ed.). Handbook of art therapy (pp. 313-325). New York, London: The Guilford.

Yılmaz, T. (2017). Klinik psikolojide sanat ve sanat uygulamaları. Tykhe Sanat ve Tasarm Dergisi, 2(2), 32-43. Erişim adresi: http://tykhedergi.duzce.edu.tr/Dokumanlar/tykhedergi/Dosyalar/Say\%C4\%B1_2\%20ma_3.pdf

\section{EXTENDED ABSTRACT}

This research was carried out in order to find out the current status regarding use of Visual Arts Education as a complementary treatment method in units offering psychiatric services in hospitals according to healthcare professionals' (clinicians, assistant doctors, psychologists, nurses and/or social workers) views. The sample consisted of healthcare staff working in psychiatry, child and adolescent 
psychiatry departments and community mental health centers (CMHC) under three different universityrun hospitals and two training and research hospitals affiliated to the Ministry of Health.

The population of this research is Ankara, the Turkish capital. Due to the limitations, the sample of the research consisted of healthcare professionals working for the following health institutions: Ankara Hacettepe University Medical Faculty Hospital Psychiatry Department, Ankara University Medical Faculty Cebeci Research and Application Hospital Child and Adolescent Psychiatry Department, Ankara University Medical Faculty Cebeci Research and Application Hospital Psychiatry Department, Ankara Gazi University Health Research and Application Center Child and Adolescent Psychiatry Department, Ankara Gazi University Health Research and Application Hospital Psychiatry Department, Dış kapı Training and Research Hospital Community Mental Health Center, and Dr. Abdurahman Yurtaslan Ankara Oncology Training and Research Hospital Andiçen Community Mental Health Center. This group consisted of healthcare personnel working in related units within 3 University hospitals with mental health and diseases, children and adolescent mental health and diseases and TRSM units in Ankara and 2 training and research hospitals affiliated to the Ministry of Health.

This is a descriptive study conducted with quantitative survey model. To put it more clearly, descriptive survey model was used to picture the current situation concerning treatment through visual arts in units offering psychiatric services in hospitals and health institutions within the sample group. Also, a questionnaire was used as a data collection tool in quantitative research in search of answer to the question "What is the current situation in the implementation of visual arts works as complementary treatment in units of hospitals where psychiatric services are provided?". The researcher created a questionnaire with considerable aid of the literature. For the draft questionnaire, learned opinion was obtained from a group of experts including 1 art educator, 1 special visual arts specialist, 1 psychologist, 1 child psychiatrist and 1 special educator. Field concent validity of the questionnaire form was checked again by following expert opinion.

In this research, which was carried out to reveal the use of treatment through visual arts in hospitals in Ankara, the data were collected by means of the questionnaire developed by the researcher. The collected data were computerized and the items in the questionnaire were interpreted using frequency and percentage statistics. Analyses were made with SPSS 22. Graphs were drawn by using the Excel. Besides, answers to the open-ended questions at the end of the questionnaire were analyzed in depth and categories were created using the content analysis method.

The results are given below concerning therapy through visual arts according to the healthcare professionals (clinicians, assistant doctors, psychologists, nurses and/or social workers) working at psychiatry units of hospitals in the central Ankara. In line with the opinions of the healthcare personnel participating in the study; it was stated that (a) $49 \%$ of the psychiatric units performed the treatment through visual arts; (b) treatments were issued by different professional groups (doctor, nurse, care assistant, art therapy specialist, visual arts teacher, social worker) however, they found it more appropriate to be given by a team of art therapists with a rate of $36 \%$ and a team of experts with a rate of $32 \%, 36.6 \%$ believed that visual arts teachers should be in charge of providing therapy rehabilitation and/or training through visual arts; (c) $73.23 \%$ of the methods and/or techniques used were not answered and/or declared to be uninformed in addition to this $9.86 \%$ organize ceramic and painting techniques and applications as a part of their work in that unit ; (d) they consider "clay-ceramic" as the most effective application in their fields and second highest preference was made about crayons, which is in the second rank as a visual arts practice proposed in the first place; (e) in that area $35.2 \%$ see the therapy "essential" . Furthermore, It was found that (f) $69 \%$ of the health personnel participating in the study requested training for the use of visual arts as treatment/therapy. However, Those who expressed unwillingness constituted $14 \%$, while $13 \%$ stated no view. The last $4 \%$ were found to be unsure.

The following recommendations were brought for practical reference: In-service training should be run addressing healthcare professionals to uplift their current levels of knowledge and skills about teaching techniques and practical applications for use in therapy with visual arts. As for future studies: Researchers who are interested in this field might; replicate this research with healthcare personnel in a different province, replicate the research with doctors only, replicate the research with intermediate health staff only (nurses, psychologists, etc.). 